Prepared in cooperation with the Minnesota Pollution Control Agency

\title{
Contaminants of Emerging Concern in Ambient Groundwater in Urbanized Areas of Minnesota, 2009-12
}

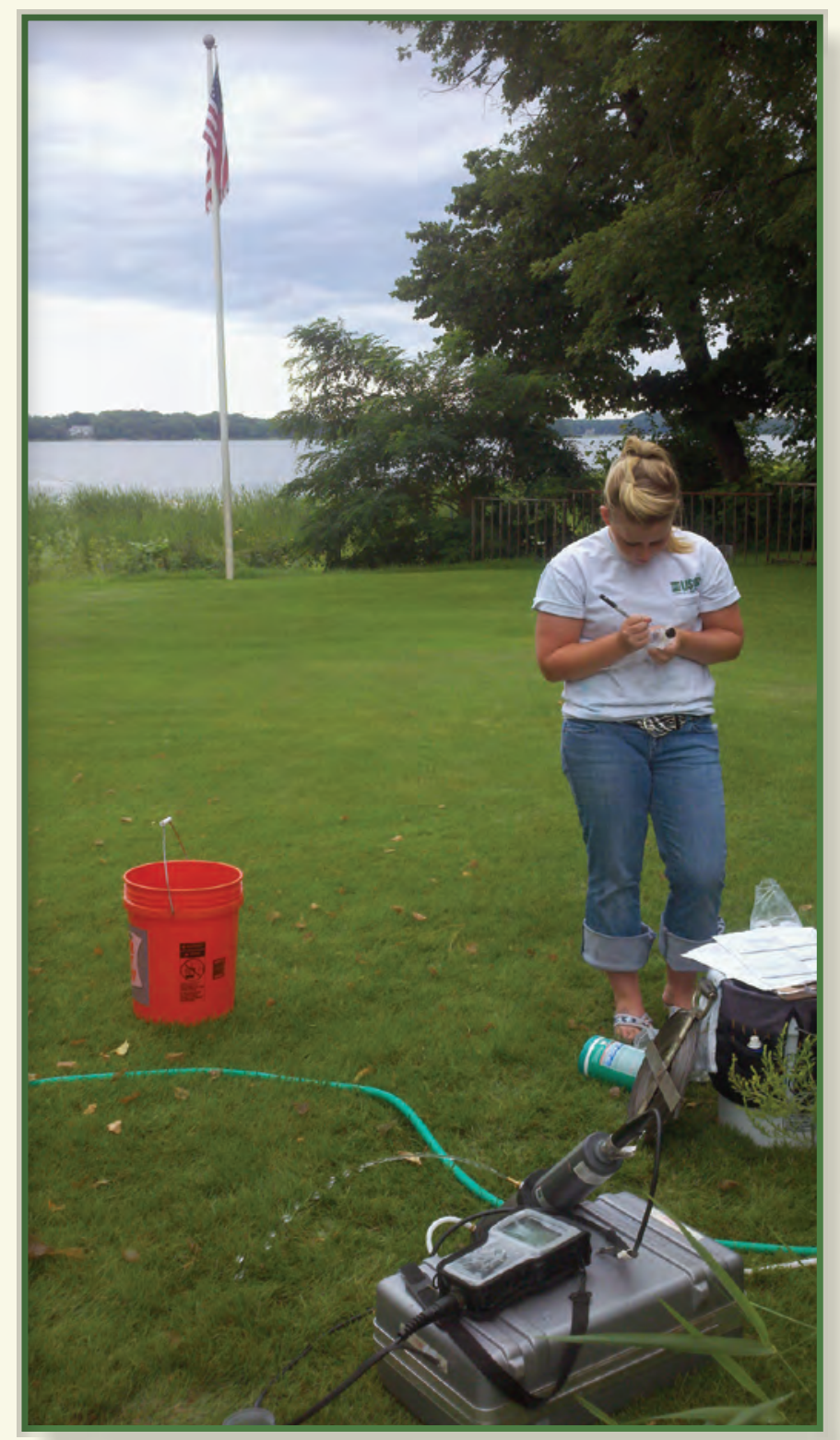

Scientific Investigations Report 2014-5096

Version 1.2, September 2014 
Cover photograph. Water-level and water quality measurement in a domestic well, White Bear Lake, Minnesota, 2011. Photograph by Perry M. Jones, U.S. Geological Survey. 


\section{Contaminants of Emerging Concern in Ambient Groundwater in Urbanized Areas of Minnesota, 2009-12}

By Melinda L. Erickson, Susan K. Langer, Jason L. Roth, and Sharon E. Kroening

Prepared in cooperation with the Minnesota Pollution Control Agency

Scientific Investigation Report 2014-5096

Version 1.2, September 2014 


\title{
U.S. Department of the Interior SALLY JEWELL, Secretary
}

\section{U.S. Geological Survey Suzette M. Kimball, Acting Director}

\author{
U.S. Geological Survey, Reston, Virginia: 2014 \\ First release: 2014 \\ Revised: September 2014 (ver. 1.2)
}

\begin{abstract}
For more information on the USGS - the Federal source for science about the Earth, its natural and living resources, natural hazards, and the environment, visit http://www.usgs.gov or call 1-888-ASK-USGS.

For an overview of USGS information products, including maps, imagery, and publications, visit http://www.usgs.gov/pubprod

To order this and other USGS information products, visit http://store.usgs.gov
\end{abstract}

Any use of trade, firm, or product names is for descriptive purposes only and does not imply endorsement by the U.S. Government.

Although this information product, for the most part, is in the public domain, it also may contain copyrighted materials as noted in the text. Permission to reproduce copyrighted items must be secured from the copyright owner.

Suggested citation:

Erickson, M.L., Langer, S.K., Roth, J.L., and Kroening, S.E., 2014, Contaminants of emerging concern in ambient groundwater in urbanized areas of Minnesota, 2009-12 (ver. 1.2, September 2014): U.S. Geological Survey Scientific Investigations Report 2014-5096, 38 p., with appendix, http://dx.doi.org/10.3133/sir20145096.

ISSN 2328-0328 (online) 


\section{Acknowledgments}

Minnesota Pollution Control Agency (MPCA) hydrologists David Duffey, Sharon Kroening, and Gerald Flom, and MPCA student workers Mark Lunda, Meaghan McGinn, and Sophia Vaughan collected the groundwater samples for this study. In November 2008, Minnesota voters approved a three-eighths of 1 percent increase in the State sales tax rate under the Clean Water, Land and Legacy Amendment. Approximately 33 percent of the funds were dedicated to a Clean Water Fund to protect, enhance, and restore water quality in lakes, rivers, streams, and groundwater. Funding for this study was provided by the State of Minnesota's Clean Water Fund and the U.S. Geological Survey's Cooperative Water Program. 



\section{Contents}

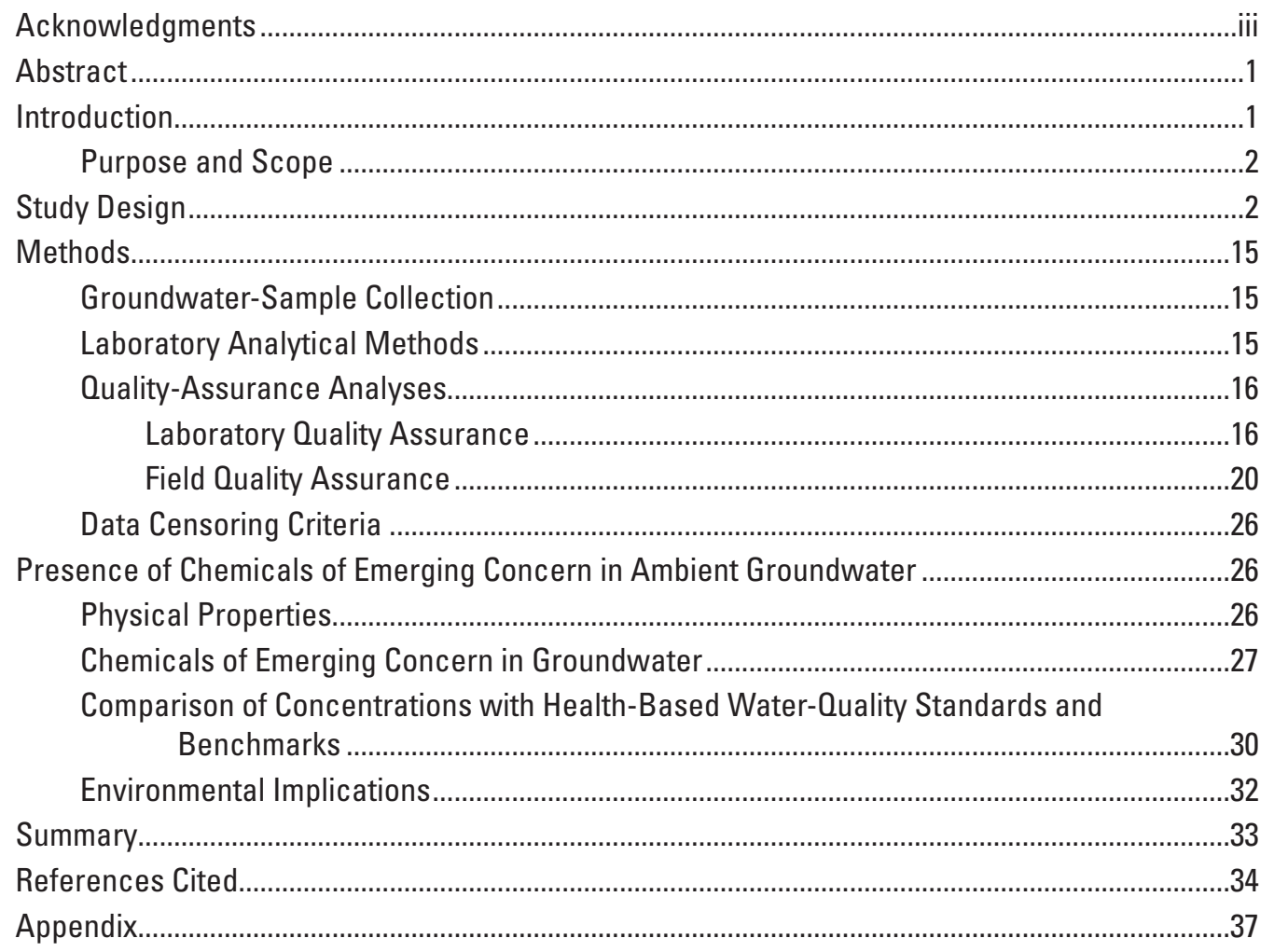

\section{Figures}

1. Map showing areal extent of vulnerable aquifers targeted for groundwater sampling and wells sampled in the Minnesota Pollution Control Agency ambient groundwater monitoring network for this study, 2009-12 ..............................................

2. Map showing location of sampled wells, 2009-12 …...................................................

3. Graph showing number of detections of selected contaminants of emerging concern in groundwater samples from urbanized areas of Minnesota, 2009-12............30

4. Map showing sampled well locations and number of detection of contaminants of emerging concern in groundwater samples from urbanized areas of Minnesota, 2009-12. 


\section{Tables}

1. Selected information for wells sampled for this study ................................................ 6

2. Analytical schedules, chemicals, and chemical categories of chemicals analyzed in groundwater samples.

3. Summary of chemical recoveries for laboratory reagent-water spike samples related to sample sets for this study, 2009-12

4. Summary of recoveries for surrogate compounds and isotope dilution standards analyzed in groundwater samples, 2009-12.

5. Chemicals detected in more than one laboratory reagent-water blank sample

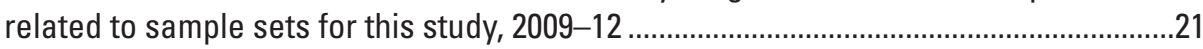

6. Concentrations of chemicals detected in field equipment-blank samples, 2009-12 ......22

7. Summary of field matrix spike recoveries from groundwater samples collected in Minnesota, 2009-12

8. Summary of well depths and physical properties in unfiltered groundwater, Minnesota, 2009-12

9. Detected chemicals and maximum concentration of contaminants of emerging concern analyzed in groundwater samples, Minnesota, 2009-12

10. Detection frequency of contaminants of emerging concern by use of water, aquifer type, and land use or monitoring type, Minnesota, 2009-12.

11. Health-based water quality standards and benchmarks 1 for chemicals analyzed for this study

\section{Conversion Factors}

Inch/Pound to SI

\begin{tabular}{lccc}
\hline & Multiply & By & To obtain \\
\hline & Length & \\
\hline foot $(\mathrm{ft})$ & 0.3048 & meter $(\mathrm{m})$ & \\
\hline
\end{tabular}

SI to Inch/Pound (used for analytical methods)

\begin{tabular}{lll}
\hline \multicolumn{1}{c}{ Multiply } & By & \multicolumn{1}{c}{ To obtain } \\
\hline centimeter $(\mathrm{cm})$ & Length & \\
\hline & 0.3937 & inch (in.) \\
\hline liter $(\mathrm{L})$ & Volume & \\
liter $(\mathrm{L})$ & 1.057 & quart (qt) \\
& 0.2642 & gallon (gal) \\
\hline gram (g) & Mass & \\
milligram (mg) & 0.03527 & ounce, avoirdupois (oz) \\
\hline
\end{tabular}


Temperature in degrees Celsius $\left({ }^{\circ} \mathrm{C}\right)$ may be converted to degrees Fahrenheit $\left({ }^{\circ} \mathrm{F}\right)$ as follows:

${ }^{\circ} \mathrm{F}=\left(1.8 x^{\circ} \mathrm{C}\right)+32$

Horizontal coordinate information is referenced to the North American Datum of 1983 (NAD 83).

Concentrations of chemical constituents in water are given in milligrams per liter $(\mathrm{mg} / \mathrm{L})$, micrograms per liter $(\mu \mathrm{g} / \mathrm{L})$, or nanograms per liter $(\mathrm{ng} / \mathrm{L})$.

Specific conductance is given in microsiemens per centimeter at 25 degrees Celsius $(\mu \mathrm{S} / \mathrm{cm}$ at $\left.25^{\circ} \mathrm{C}\right)$.

\section{Abbreviations}

$\begin{array}{ll}\text { CEC } & \text { contaminant of emerging concern } \\ \text { DEET } & \text { N,N-diethyl-meta-toluamide } \\ \text { DO } & \text { dissolved oxygen } \\ \text { E } & \text { estimated } \\ \text { EAC } & \text { endocrine active chemical } \\ \text { EPA } & \text { U.S. Environmental Protection Agency } \\ \text { FYROL CEF } & \text { Tris(2-chloroethyl) phosphate } \\ \text { GIS } & \text { geographic information system } \\ \text { HBSL } & \text { Health-Based Screening Levels } \\ \text { HBV } & \text { Health-Based Value (Minnesota Department of Health) } \\ \text { HHCB } & \text { hexahydrohexamethylcyclopentabenzopyran } \\ \text { HRL } & \text { Health Risk Limit (Minnesota Department of Health) } \\ \text { IDS } & \text { isotope dilution standard } \\ \text { MCL } & \text { Maximum Contaminant Level (U.S. Environmental Protection Agency) } \\ \text { MDH } & \text { Minnesota Department of Health } \\ \text { MPCA } & \text { Minnesota Pollution Control Agency } \\ \text { NFM } & \text { National Field Manual for the Collection of Water-Quality Data } \\ \text { NLCD } & \text { (U.S. Geological Survey) } \\ \text { NWOL } & \text { National Land Cover Dataset } \\ \text { OGRL } & \text { National Water Quality Laboratory (U.S. Geological Survey) } \\ \text { PCFF } & \text { Organic Chemistry Research Laboratory (U.S. Geological Survey) } \\ \text { PhAC } & \text { Personal Computer Field Forms (U.S. Geological Survey) } \\ \text { B } & \text { pharmaceutically active compound } \\ \text { SSTS } & \text { registered trademark } \\ \text { TCMA } & \text { subsurface sewage treatment systems for wastewater disposal } \\ \text { USGS } & \text { Twin Cities Metropolitan area } \\ & \text { U.S. Geological Survey } \\ & \end{array}$





\title{
Contaminants of Emerging Concern in Ambient Groundwater in Urbanized Areas of Minnesota, 2009-12
}

\author{
By Melinda L. Erickson, ${ }^{1}$ Susan K. Langer, ${ }^{1}$ Jason L. Roth, ${ }^{1}$ and Sharon E. Kroening ${ }^{2}$
}

\section{Abstract}

A study of contaminants of emerging concern (CECs) in ambient groundwater in urbanized areas of Minnesota was completed by the U.S. Geological Survey in cooperation with the Minnesota Pollution Control Agency. For this study, water samples were collected from November 2009 through June 2012 from 118 wells located in different land-use settings. The sampled wells primarily were screened in vulnerable sand and gravel aquifers (surficial and buried glacial aquifers) or vulnerable bedrock aquifers such as the Prairie du Chien-Jordan aquifer. Sampled well depths ranged from 9 to 285 feet below land surface. Water samples were collected by Minnesota Pollution Control Agency staff. The water samples were analyzed at U.S. Geological Survey laboratories for steroidal hormones, human-use pharmaceutical compounds, human- and animaluse antibiotics, and a broad suite of organic chemicals associated with wastewater. Reported detections were censored and not counted as detections in the data analyses if the chemical was detected in a laboratory or field blank at a similar concentration.

During this study, 38 out of 127 CECs analyzed were detected among all water samples collected. Three of the detected CECs, however, were analyzed using two different analytical methods, so 35 distinct chemicals were detected. The number of detections of CECs in individual water samples ranged from 0 to 10 . The three wells in proximity to landfills had the most CEC detections. One or more CECs were detected in a total of 43 samples ( 35 percent); no CECs were detected in 80 samples.

Of the 127 CECs included for analysis in this study, 28 have established enforceable or non-enforceable healthbased water-quality standards or benchmarks. Fourteen of the 35 chemicals detected in this study have established waterquality standards, whereas 21 of the chemicals detected have no established standard or benchmark. All detections in this study were less than established health-based water-quality standards, although $p$-cresol was detected at a concentration nearing a health-based water quality standard. Four of the six

\footnotetext{
${ }^{1}$ U.S. Geological Survey.
}

${ }^{2}$ Minnesota Pollution Control Agency. most frequently detected chemicals - azithromycin, diphenhydramine, tributyl phosphate, and lincomycin - have no health-based water-quality standards or benchmarks.

The antibiotic sulfamethoxazole was the most frequently detected CEC, detected in a total of 14 of 123 samples (11.4 percent) by one or both analytical methods that include sulfamethoxazole as an analyte. Most (11 of 14, or 79 percent) of the detections of sulfamethoxazole were in samples from domestic wells or monitoring wells located in areas where septic systems or potentially leaking centralized sewers are prevalent. The chemical $N, N$-Diethyl-meta-toluamide (DEET) was detected at the highest concentration of any CEC, at 7.9 micrograms per liter. Bisphenol A was detected second most frequently of all chemicals. DEET and Bisphenol A were detected most frequently in wells in proximity to closed landfills. Samples from bedrock wells, most of which are drinking water wells that are deeper than glacial wells, had a higher percentage of wells with CEC detections compared to samples from wells completed in glacial aquifers. The higher dissolved oxygen concentrations and lower specific conductance for the bedrock wells sampled indicate shorter duration flow paths from the land surface to these wells than for wells completed in glacial aquifers.

\section{Introduction}

Approximately 78 percent of the population of Minnesota uses groundwater as drinking water (Kenny and others, 2009). Groundwater also provides critical base flow to streams and rivers, and groundwater supports lake and wetland water levels (Winter and others, 1998; Rosenberry and LaBaugh, 2008). Groundwater flowing into streams, rivers, lakes, and wetlands also can transport natural and anthropogenic chemicals present in the groundwater into these surface-water bodies. It is, therefore, important to understand the quality and vulnerability of groundwater in Minnesota to anthropogenic contamination.

Monitoring is essential to evaluate the status of groundwater quality and determine whether the State of Minnesota has enough clean groundwater to meet its citizens' needs. Monitoring the amount of chemicals in the State's groundwater helps policy-makers gage whether land-use practices 
degrade water quality and whether practices put in place to minimize groundwater contamination are working.

Contaminants of emerging concern (CECs; also called chemicals of emerging concern or emerging contaminants in the literature) are chemicals that are not commonly monitored or regulated in the environment. Examples of CEC chemical classes include prescription and over-the-counter pharmaceuticals, fire retardants, pesticides, personal-care products, hormones, and detergents. Some CECs are human-made, some are naturally occurring, and some also are endocrine active chemicals (EACs). In animals, the effects of exposure to EACs include reduced reproductive success, reduced survival, altered sex ratios, occurrence of intersex, and developmental abnormalities (Streets and others, 2008). Human exposure to EACs may result in diminished intelligence, altered behavior and development, and decreased immunity to disease. EACs are capable of disrupting any of the many parts or the endocrine (hormone) system. Many EACs and pharmaceutically active compounds (PhACs) are designed to benefit humans or animals when ingested, for example the antibiotic sulfamethoxazole or the hormone ethynyl estradiol. Some EACs and PhACs may, however, have an unwanted biological effect, such as the feminization of male fish, in the environment (Halling-Sorenson and others, 1998). Recent studies have documented the presence of CECs, including EACs, in Minnesota surface water and groundwater (Lee and others, 2004; Tornes and others, 2007; Lee and others, 2008; Erickson, 2012) and nationwide (Zogorski and others, 2006; DeSimone and others, 2009; Toccalino and Hopple, 2010).

This study was designed to assess the occurrence and distribution of CECs in ambient groundwater in urbanized areas that are vulnerable to contamination from non-agricultural chemicals and was completed by the U.S. Geological Survey (USGS) in cooperation with the Minnesota Pollution Control Agency (MPCA).

\section{Purpose and Scope}

The purpose of this report is to present an assessment on the presence of CECs in ambient groundwater in urbanized areas in Minnesota. The assessment was based on analyses of 127 CECs in samples of groundwater collected from November 2009 through June 2012 from 118 wells completed in sand and gravel aquifers (surficial and buried glacial aquifers) or bedrock aquifers such as the Prairie du Chien-Jordan aquifer located in different land-use setting throughout the State of Minnesota.

\section{Study Design}

This study was designed to assess the occurrence and distribution of CECs in groundwater in urbanized areas that are vulnerable to contamination from non-agricultural chemicals. The study design was presented in Erickson (2012) and
Kroening (2012) and is presented again in this section of the report. The study used wells from the MPCA's ambient groundwater monitoring network to determine the occurrence of contamination from CECs in ambient groundwater in Minnesota. The broad suite of CECs analyzed in groundwater samples for this study included chemicals typically found in municipal wastewater: steroidal hormones, pharmaceuticals, antibiotics, and other organic chemicals.

The MPCA maintains an ambient groundwater monitoring network (hereinafter referred to as the "network") to determine if non-agricultural chemical contamination is present in the groundwater and to track any trends in contamination (Kroening, 2013). The MPCA monitoring network focuses on these specific chemical types to meet State and Federal authorities and requirements. The MPCA monitoring efforts complement its charge to minimize groundwater contamination from all other chemicals.

The MPCA network primarily is used to monitor groundwater expected to represent broad groundwater conditions and also is most likely to be contaminated with nonagricultural chemicals. The network consisted of about 200 wells as of 2013. Wells that are known to be or suspected to be affected by known point sources of contamination, such as leaking petroleum product storage tanks, Superfund sites, or landfills, are not part of the network (Kroening, 2012). Typically, shallow aquifers are sampled for this network because these aquifers tend to be the most vulnerable to contamination (Minnesota Department of Natural Resources, 2014). The network monitoring is targeted to wells completed in the vulnerable sand and gravel aquifers and vulnerable bedrock aquifers, such as the Prairie du Chien-Jordan aquifer (fig. 1), in areas that are sensitive to pollution, as described by the Minnesota Department of Natural Resources and others (Falteisek, 2013). The vulnerable parts of the aquifers contain water that infiltrated recently (that is, infiltration that fell as precipitation less than 10 years ago). Contamination caused by humans is more likely to quickly reach these vulnerable parts of the aquifers compared to the deeper, more protected aquifers, which generally are recharged by water that fell as precipitation several decades to centuries in the past (Minnesota Department of Natural Resources, 2014).

The wells in the MPCA network are used to discern the effect of urban land use on groundwater quality and constitute an "early warning system" of about 130 shallow wells placed near the water table in the sand and gravel aquifers. Most wells in the network contain water that was recharged into the groundwater within the past decade; the groundwater extracted from some of these wells is less than 1 year old (Kroening, 2013). The wells in the network are distributed among several different land-use settings to determine the effect these settings have on groundwater quality. The assessed land-use settings are (1) sewered residential, (2) septic residential, which are residential areas that use subsurface sewage treatment systems for wastewater disposal (SSTS; also known as septic systems), (3) commercial or industrial areas, and (4) undeveloped areas such as parkland or forests. The data collected from the wells 


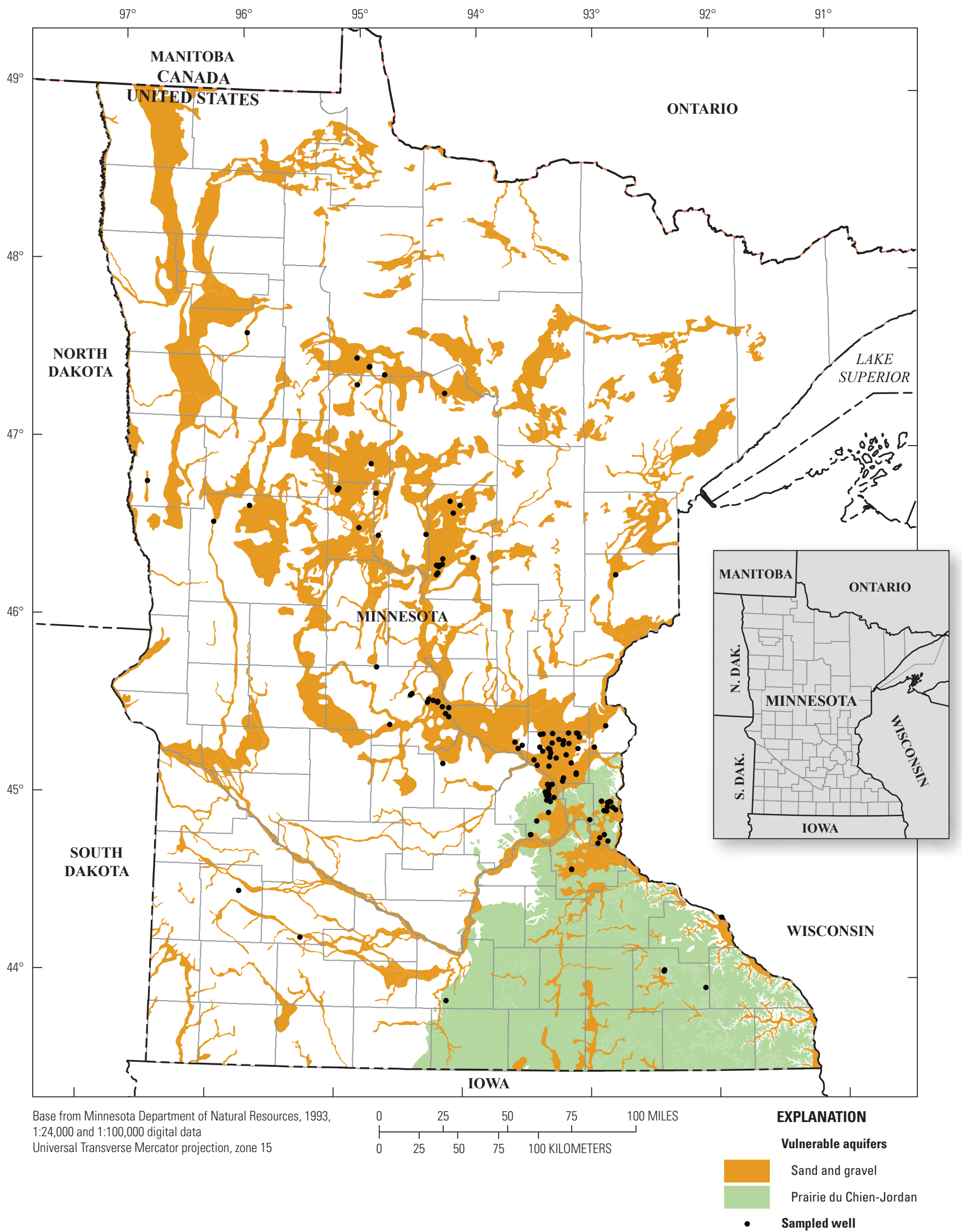

Figure 1. Areal extent of vulnerable aquifers targeted for groundwater sampling and wells sampled in the Minnesota Pollution Control Agency ambient groundwater monitoring network for this study, 2009-12. 
in the undeveloped areas provide a baseline to assess the extent of any contamination from all other land-use settings.

Wells selected and sampled as part of the network were located within fairly homogeneous settings, in terms of land use/land cover. Existing wells installed to detect known or suspected contamination are not included in the network to eliminate any biases in the results from these locations. The selection of wells for inclusion in the network was accomplished using a two-level process. The first level was to use existing geographic information system (GIS) datasets and maps to define the characteristics surrounding the existing wells and determine suitable locations for newly installed monitoring wells. The second level of the process used field reconnaissance to verify the characteristics surrounding the well were consistent with the initial GIS assessment.

The land use/land cover contributing to groundwaterquality conditions at existing wells and any newly installed wells was defined using a 1,640-foot (ft; 500-meter) circular buffer. In many cases, neither the hydraulic characteristics nor the groundwater-flow directions in the aquifer in the immediate vicinity of the well were well known, and a 1,640-ft circular buffer has been reported to adequately define the characteristics surrounding monitoring wells in a wide range of hydrogeologic settings across the Nation (Koterba, 1998). Similar land use/land cover in 75 percent or more of the $1,640-\mathrm{ft}$ circular buffer was used as a criterion to describe homogeneous settings.

Several sources of information for land use/land cover were used when evaluating existing wells for inclusion in the network and siting potential well locations. The 2001 National Land Cover Dataset (NLCD) (Homer and others, 2007) was used to delineate undeveloped and urbanized areas (Kroening, 2013). Urban land use is not designated as commercial/ industrial, sewered, or as areas with septic systems in the NLCD data. The 2005 land-use data published by the Twin Cities Metropolitan Council were used to delineate commercial/industrial areas and urban areas on centralized sewerage systems maintained by the Metropolitan Council within the 7-county Twin Cities metropolitan area (TCMA) (Kroening, 2013). Maps published by individual municipalities were used to delineate urban land-use types outside of the TCMA, and residential areas on centralized sewerage systems not maintained by the Metropolitan Council. In areas outside of the TCMA, commercial/industrial areas were delineated in municipalities with populations greater than 10,000 people. Smaller localities likely did not contain a large enough commercial/industrial sector that could be contained within a 1,640-ft circular buffer.

MPCA staff, in consultation with USGS, selected a subset of about 40 ambient wells (generally less than $200-\mathrm{ft}$ deep) per year primarily from the MPCA ambient groundwater monitoring network for sampling during the study. During 2009-12, 118 wells were sampled (figs. 1 and 2; table 1); 5 wells were sampled twice, so a total of 123 samples were collected.

Three of the 118 wells sampled had been installed to monitor groundwater affected by landfill leachate (map numbers 46, 54, and 65 on fig. 2, table 1) because landfill leachate has been identified as a source of CEC (Barnes and others, 2004; Andrews and others, 2011). All three landfills were unlined. None of the landfills were in operation at the time of sampling, and all of them ceased accepting waste 15-30 years before sample collection for this study. Two landfills had primarily accepted municipal waste, and the third landfill had primarily accepted demolition debris (Kroening, 2012).

Almost 70 percent of the wells sampled for this study were from the early warning network component of the MPCA network, which consisted mostly of wells completed in the surficial glacial aquifers. The remaining wells primarily were installed in deeper parts of the sand and gravel aquifers (buried glacial aquifers) or in vulnerable bedrock aquifers. The vulnerable bedrock aquifers from which samples were collected for this study (table 1), in descending order, are the St. Peter aquifer (contained in St. Peter Sandstone), Prairie du Chien-Jordan aquifer (contained in Prairie du Chien Group and Jordan Sandstone), and Franconia aquifer (contained in the Franconia Formation or the St. Lawrence and Franconia Formations). Information regarding these aquifers in Minnesota is provided by Adolphson and others (1981), Morey (1972), Runkel and others (2003), and Mossler (2008). Early warning network wells from all assessed land-use settings were included; however, the sampling was weighted towards wells located in unsewered (SSTS) and sewered residential areas.

Samples were collected from November 2009 through June 2012; most samples were collected during the months of April, May, and June. Sampled wells ranged from 9 to $285 \mathrm{ft}$ deep. Bedrock wells (such as those completed in the Prairie du Chien-Jordan aquifer) generally were deeper (average of 188-ft deep) than wells screened in sand and gravel aquifers (glacial sediments; average of 30-ft deep). For wells screened in glacial sediments, monitoring wells were shallower (average of 23-ft deep) than domestic wells (average of 61-ft deep).

The water samples were analyzed for steroidal hormones, human-use pharmaceutical chemicals, human- and animal-use antibiotics, and a broad suite of organic chemicals associated with wastewater, as described in table 2 , using published analytical methods (Foreman and others, 2012; Furlong and others, 2008; Meyer and others, 2007; and Zaugg and others, 2006). Samples were sent to the USGS National Water Quality Laboratory (NWQL) and the USGS Organic Geochemistry Research Laboratory (OGRL) (http://ks.water.usgs.gov/ research-lab) for analysis. Analytical results for steroidal hormones in samples collected from October 2009 through June 2010 are presented in Erickson (2012) and are not reproduced in this report. These data were, however, included in the data analysis and assessment presented in this report. 


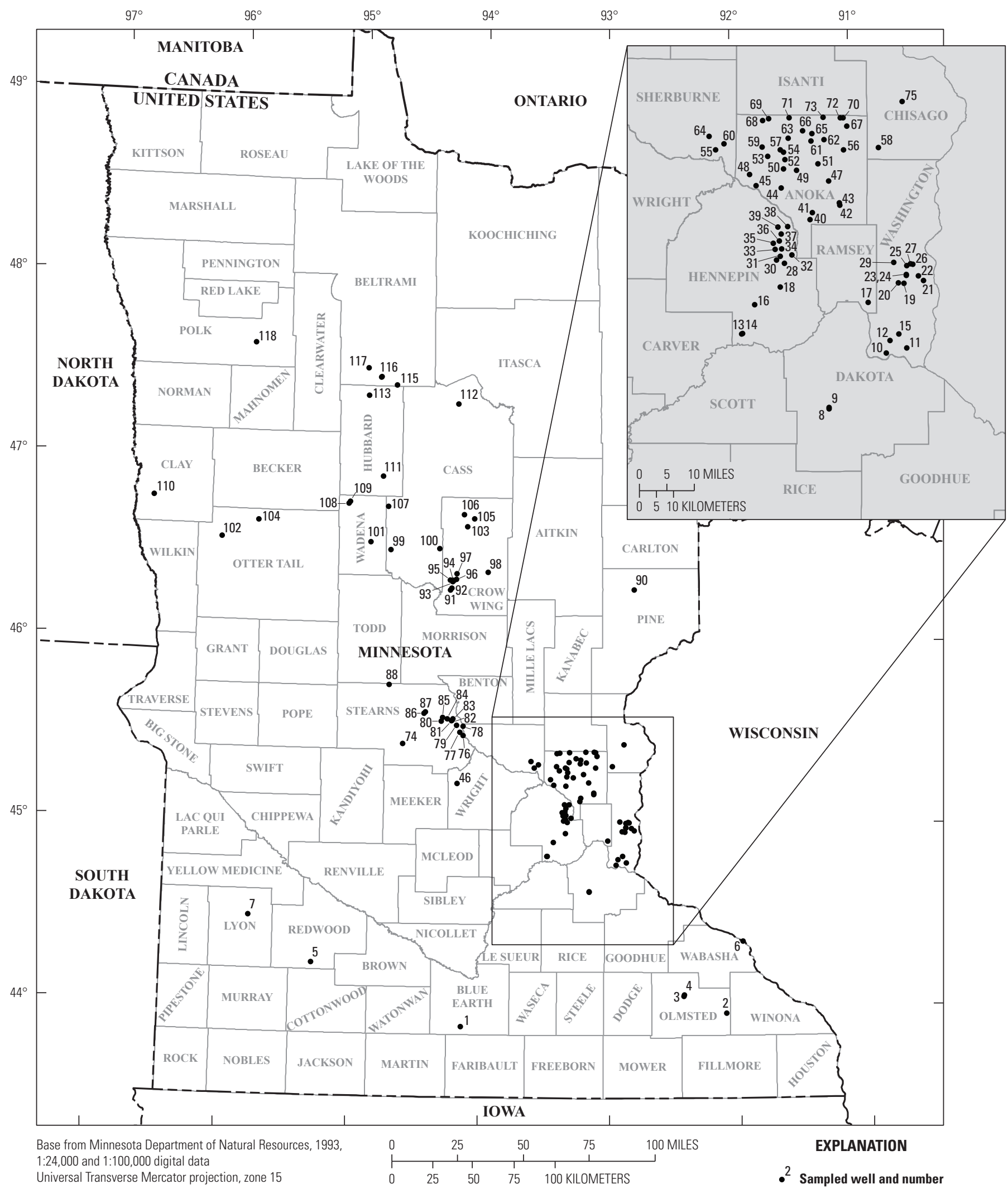

Figure 2. Location of sampled wells, 2009-12. 


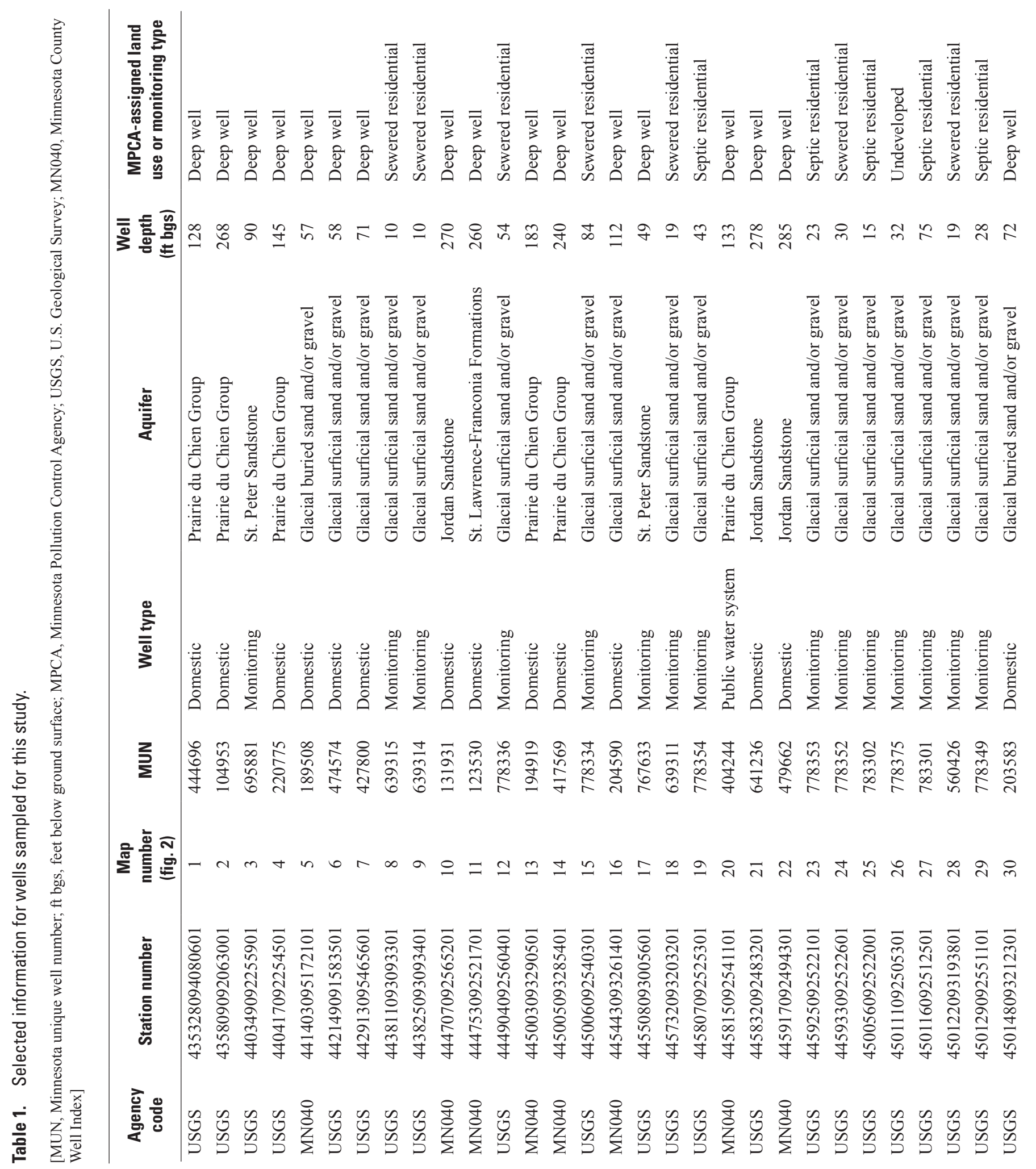




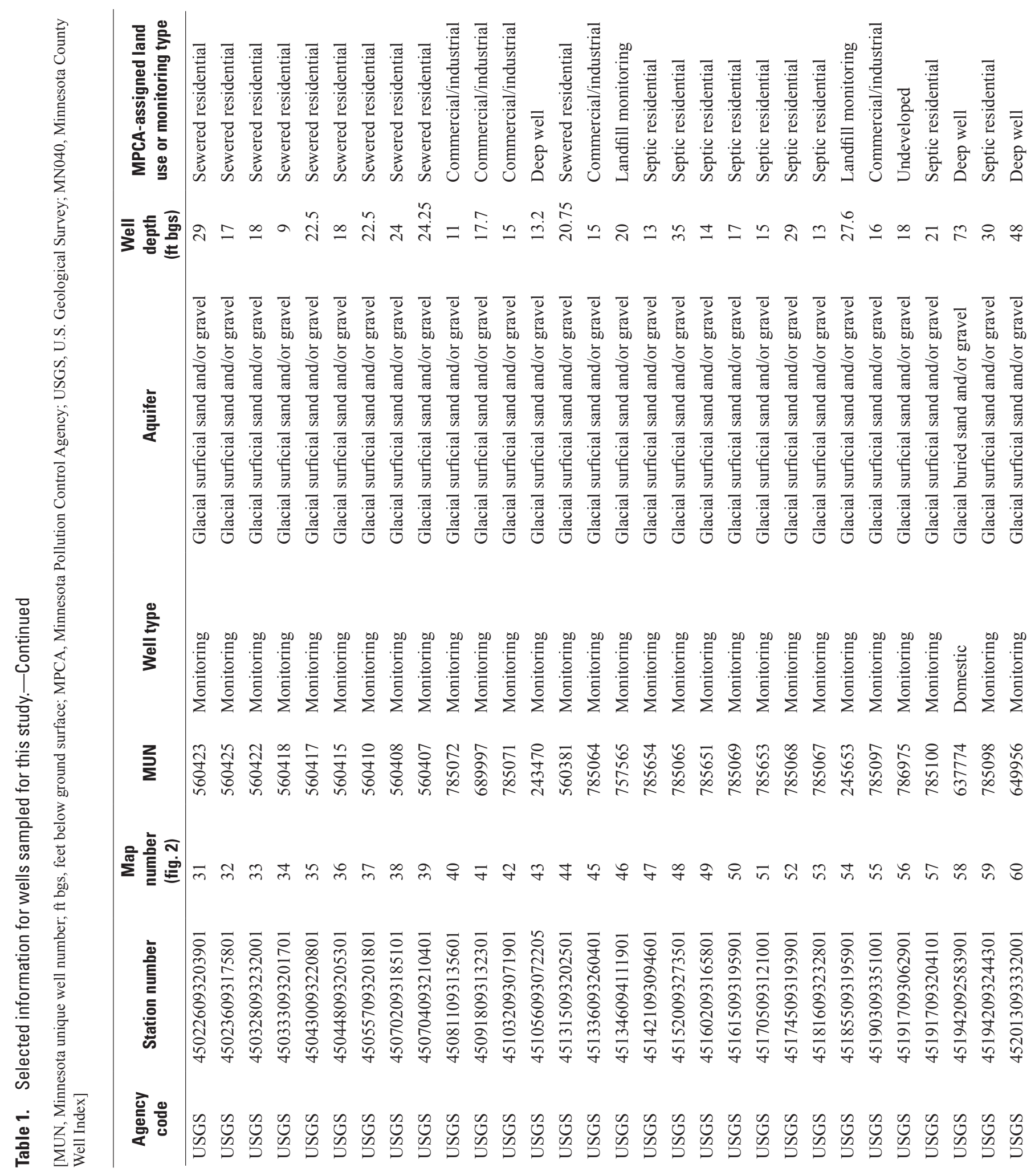




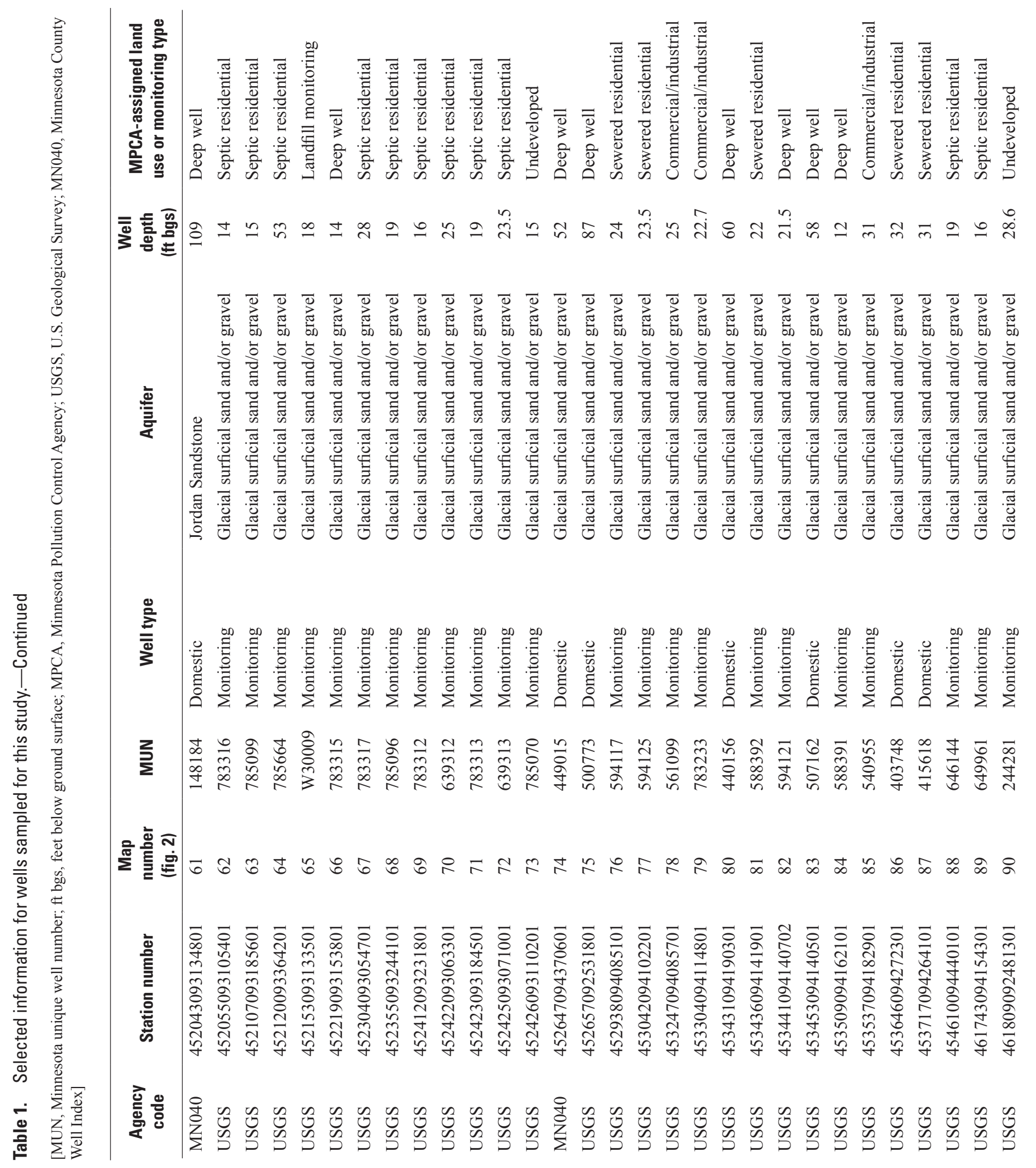




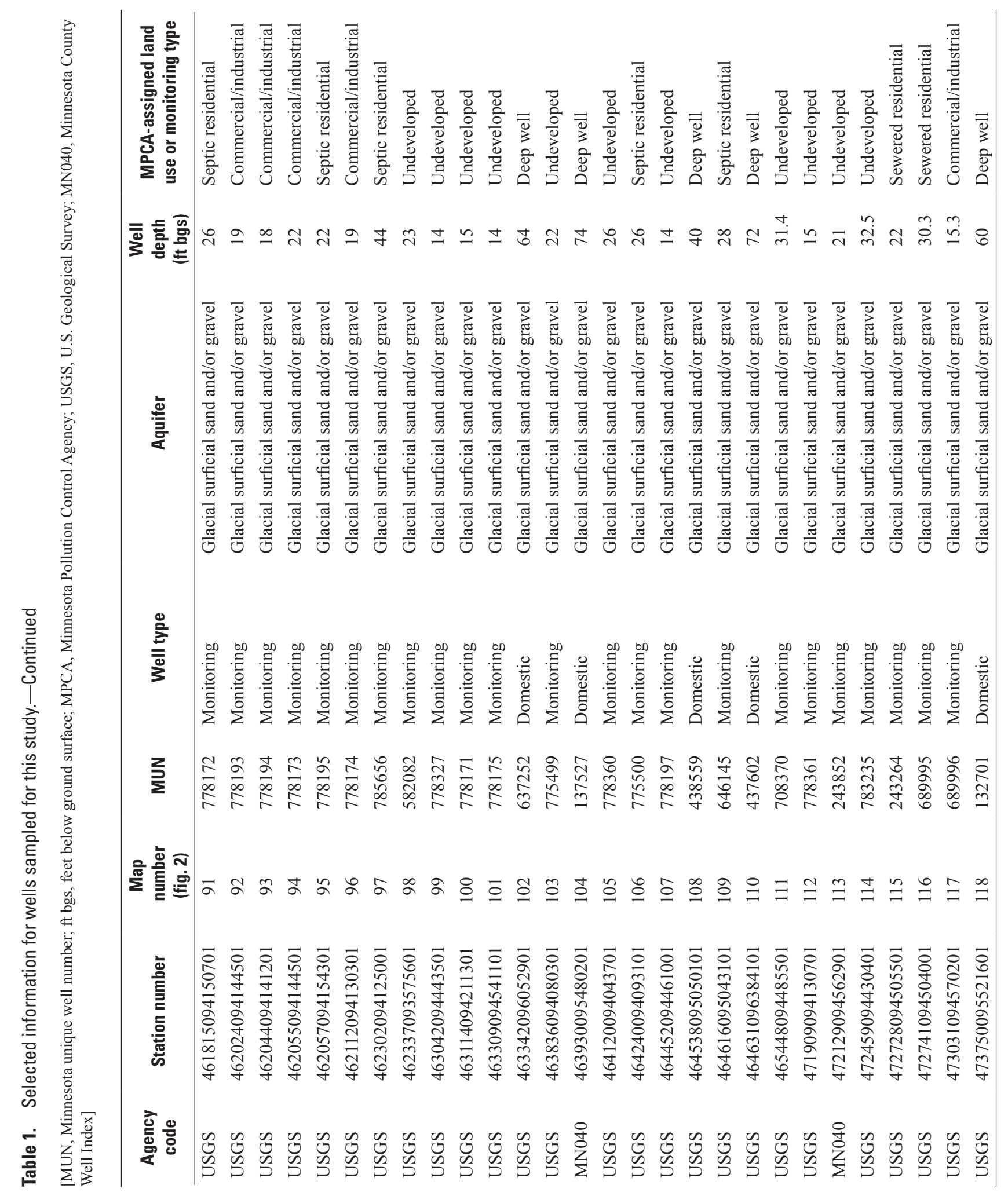




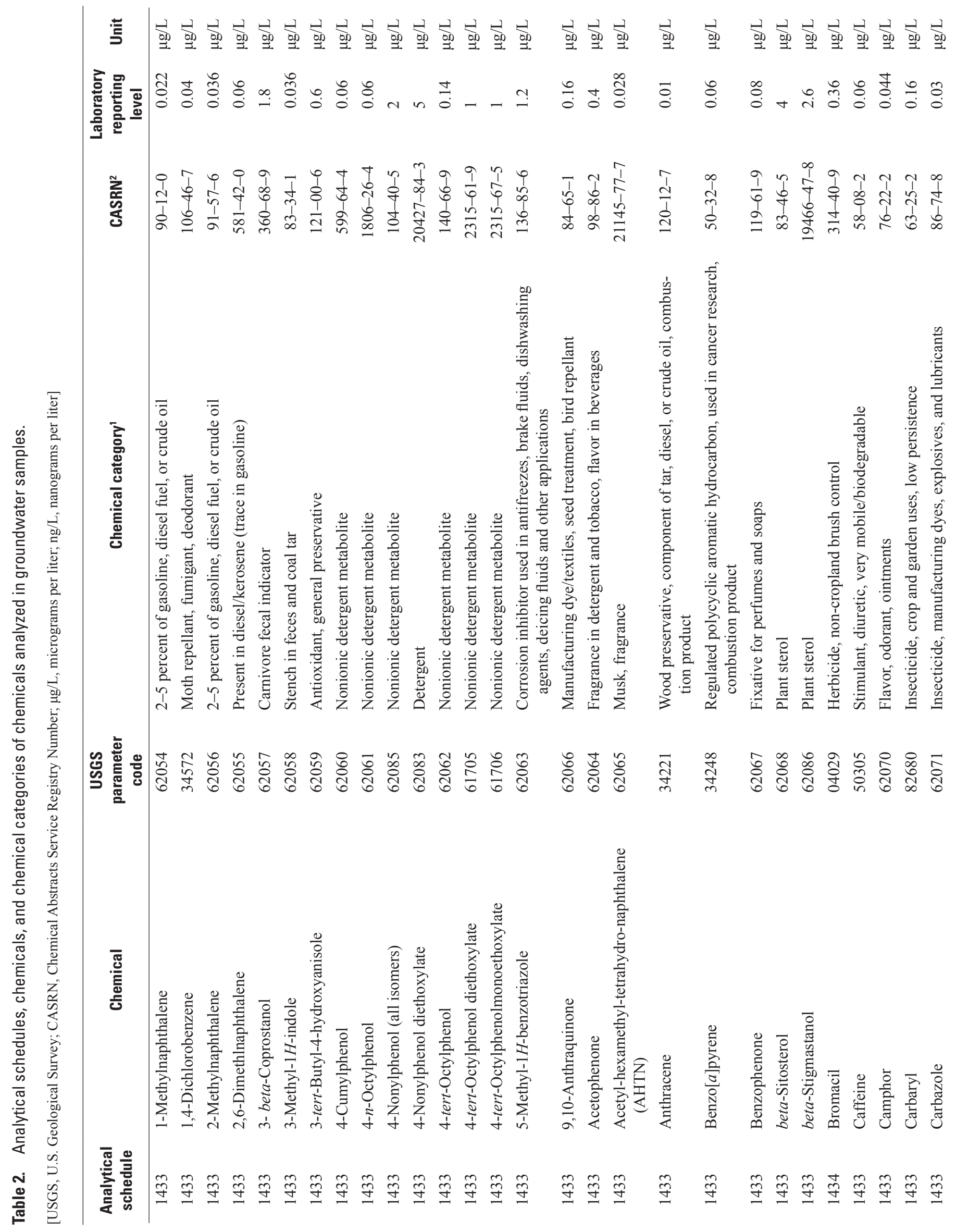




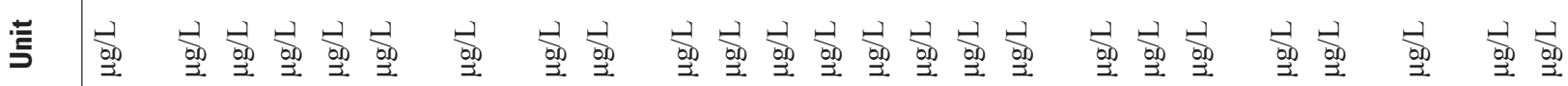

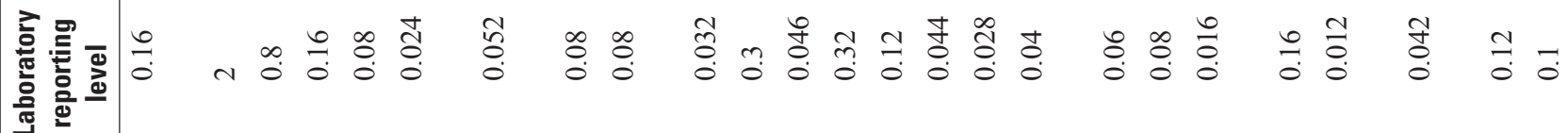

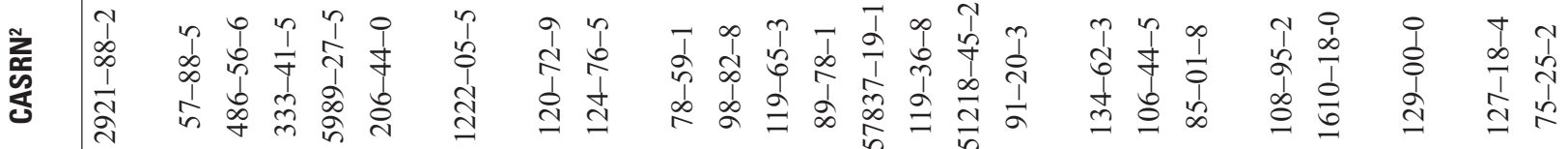

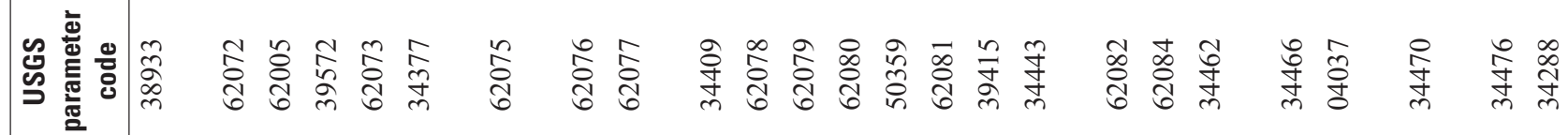

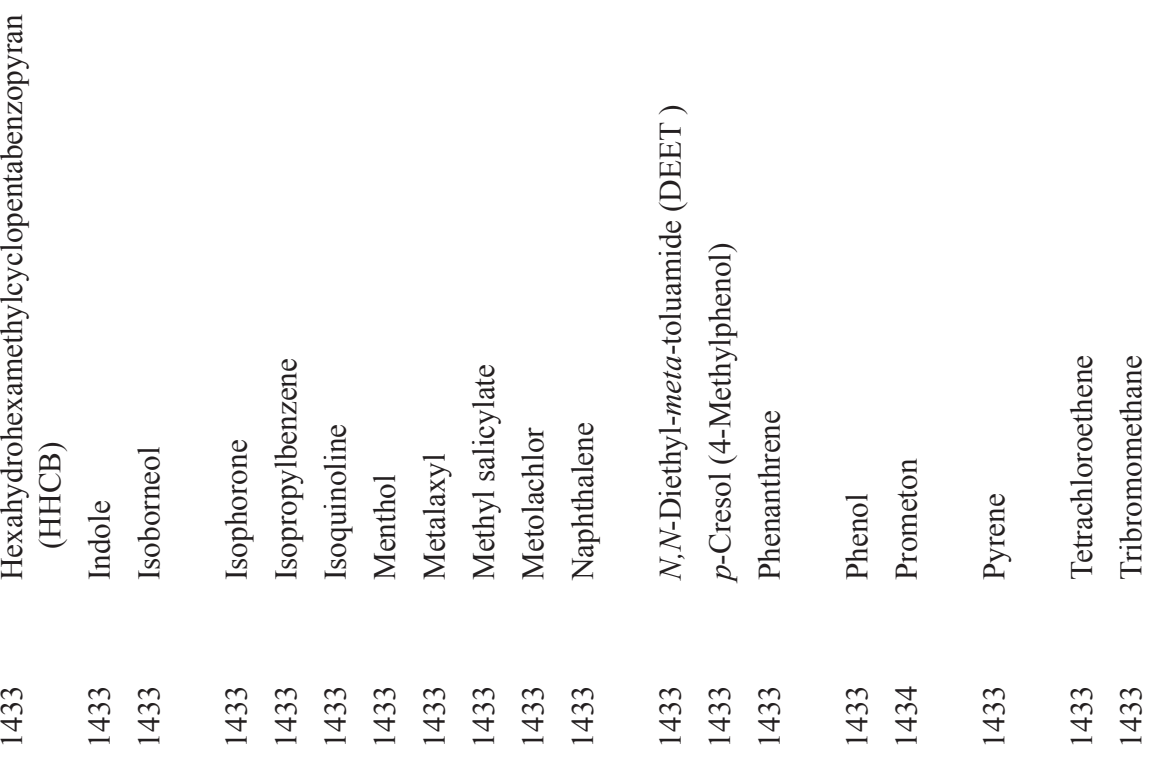




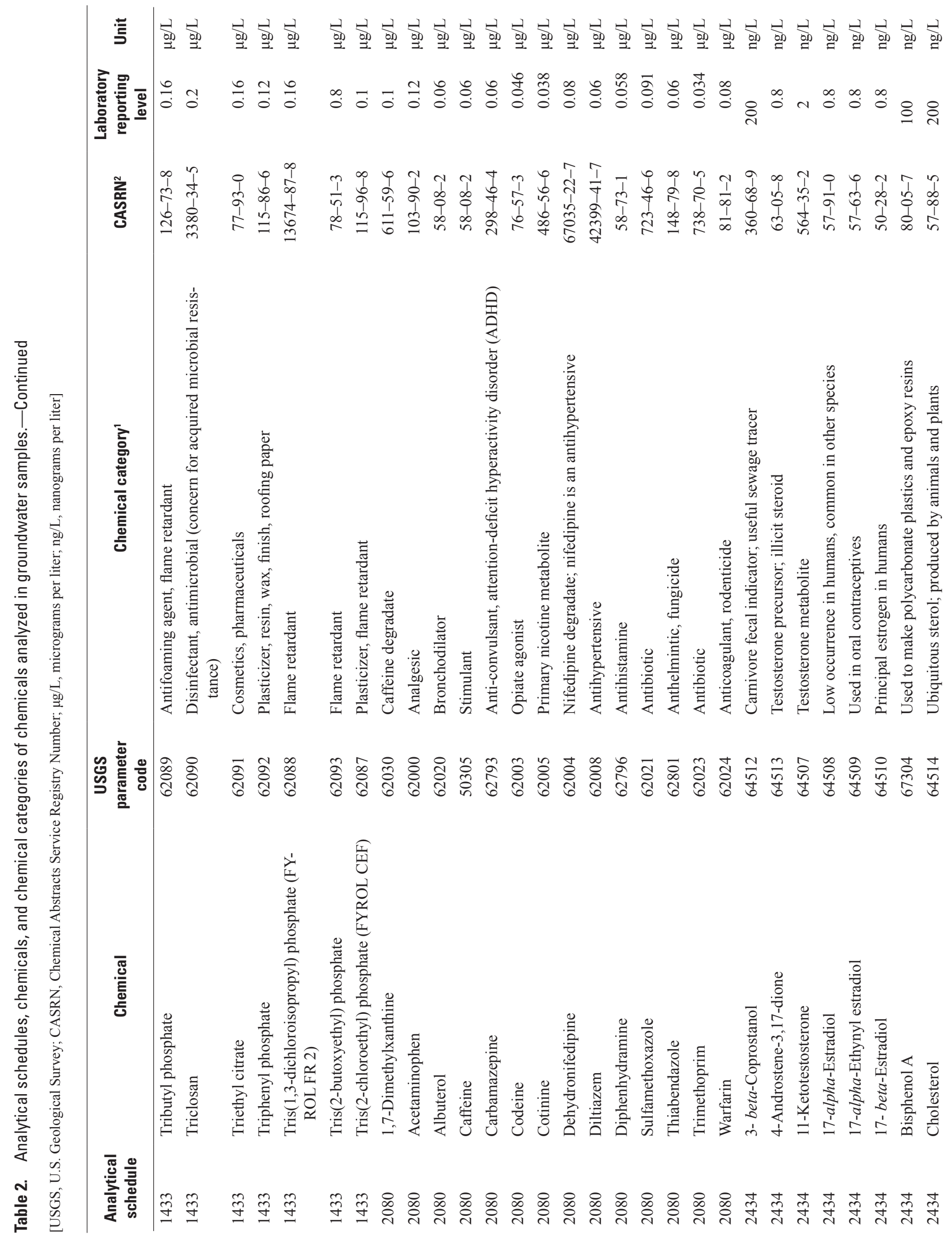




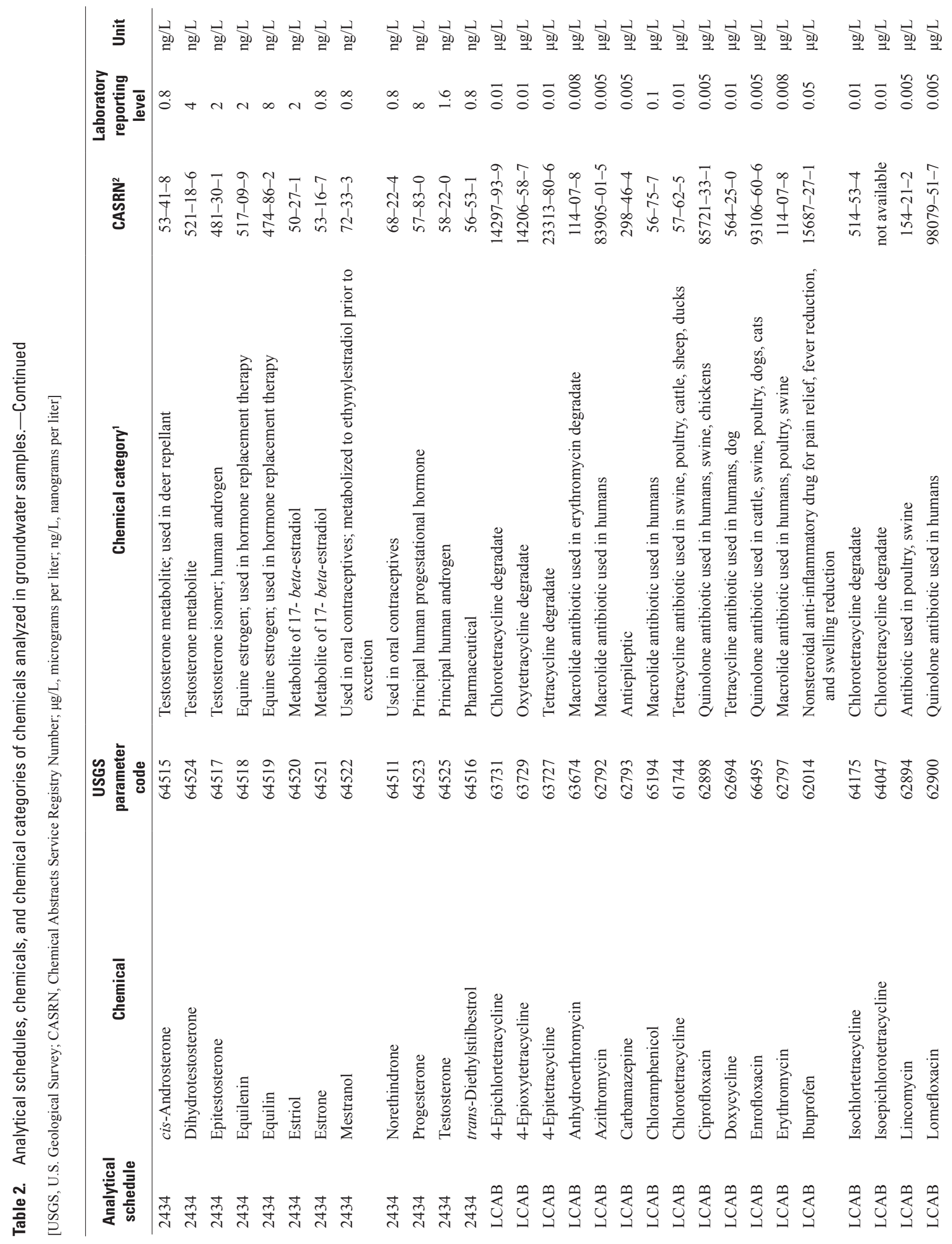




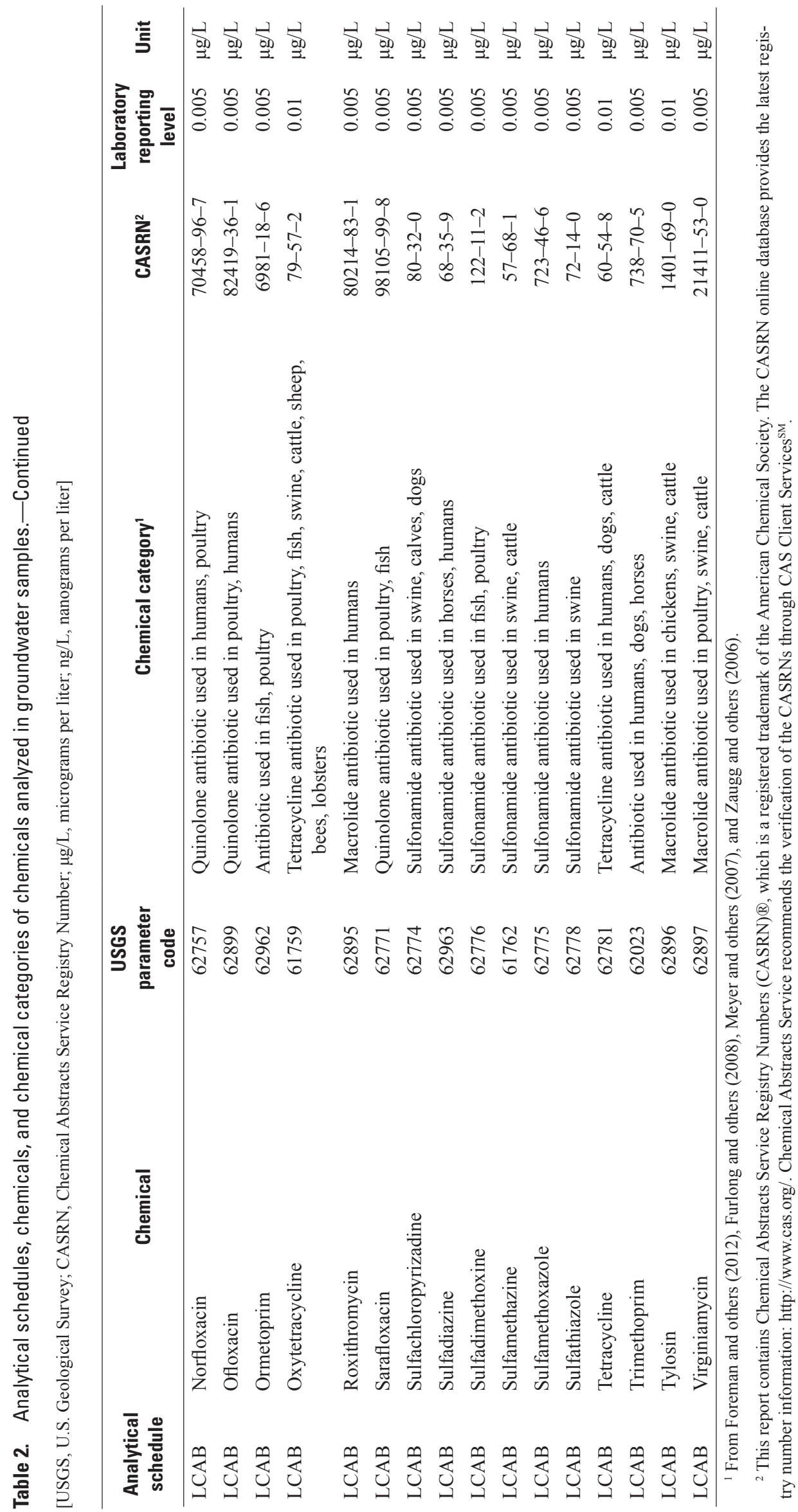




\section{Methods}

This section of the report describes field procedures used to collect the groundwater samples, laboratory analytical methods, laboratory quality-assurance and quality-control samples and analyses, field quality-assurance and quality-control samples and analyses, and data censoring criteria.

\section{Groundwater-Sample Collection}

Methods for collection of groundwater samples were presented in Erickson (2012) and are briefly described in this section. Staff from the USGS provided training to MPCA hydrologic technicians on USGS sampling protocols and on the use of the USGS Personal Computer Field Forms (PCFF) computer program, which was used to record field data. An experienced USGS hydrologic technician accompanied MPCA staff during the first week of sampling to fully train and assist MPCA staff. Staff from the MPCA collected 123 environmental water samples from 118 wells during November 2009 through June 2012, with most samples collected during April, May, and June of each year. Associated field quality-assurance samples, such as replicate samples and blank samples, were also collected. Water samples were collected by MPCA staff according to the USGS National Field Manual for the Collection of Water-Quality Data (NFM) (U.S. Geological Survey, variously dated). Staff from the USGS verified sample completeness and labeling, shipped all samples to the USGS laboratories, and entered necessary site and sample information into USGS databases.

Before collecting samples at each site, the well was purged using the submersible pump already installed in the well (domestic or public water system wells) or a submersible or peristaltic pump outfitted with polytetrafluoroethylene tubing (monitoring wells). Field properties of water, such as dissolved oxygen, $\mathrm{pH}$, specific conductance, and temperature were measured with a multiparameter sonde and recorded using the PCFF computer program as specified in the NFM. Wells were purged until field properties were stable. Samples for analysis of organic contaminants were filtered and collected in baked glass amber bottles, according to USGS protocols (Wilde and others, 2004), except that the samples for analysis using schedule 2434 were contained in new 0.5 -liter (L) high-density polyethylene bottles, as specified for that method (Foreman and others, 2012). Samples for analysis by schedule 2434 that were not processed within 3 days of receipt by the NWQL were stored in a freezer at -5 degrees Celsius $\left({ }^{\circ} \mathrm{C}\right)$ or less, until the day preceding extraction when the samples were allowed to thaw at room temperature.

Sampling equipment was cleaned between sampling sites using, in sequence, Liqui-Nox ${ }^{\circledR}$ and tap water solution, tap water, deionized water, methanol, and organic-free blank water as specified in the NFM (U.S. Geological Survey, variously dated). Sampling personnel generally refrained from using personal-care products (for example, mosquito repellant containing $N, N$-diethyl-meta-toluamide [DEET]) to avoid contamination of the samples during collection.

Field quality-assurance samples collected for this study included replicate, spike, and blank samples. Field-replicate samples were collected at 12 wells during the sampling to quantify variability between samples. Matrix spike/matrix spike duplicate samples were collected at 6 of the 118 wells to quantify potential matrix interferences in laboratory methods. Field-equipment blank samples were collected at 16 of the 118 wells to characterize any contamination potentially introduced during field activities.

\section{Laboratory Analytical Methods}

Wastewater chemicals were analyzed using NWQL schedule 1433, which consists of solid-phase extraction and gas chromatography/mass spectrometry (Zaugg and others, 2006). The method focuses on the determination of chemicals that are indicators of municipal and domestic wastewater, such as alkylphenol ethoxylate nonionic surfactants and their degradates, food additives, fragrances, antioxidants, flame retardants, plasticizers, industrial solvents, disinfectants, fecal sterols, polycyclic aromatic hydrocarbons, and high-use domestic pesticides. Briefly, water samples are filtered and then are extracted by vacuum through disposable solid-phase cartridges that contain polystyrene-divinylbenzene resin. The cartridges are then dried with nitrogen gas, and the sorbed chemicals are eluted with dichloromethane-diethyl ether. The concentrations of the wastewater chemicals are measured by capillary-column gas chromatography/mass spectrometry (Zaugg and others, 2006).

Human-health pharmaceuticals were analyzed using NWQL schedule 2080, by solid phase extraction and high-performance liquid chromatography/mass spectrometry (Furlong and others, 2008). The method quantifies 14 commonly used human pharmaceuticals in filtered-water samples. Briefly, the method uses a chemically modified styrene-divinylbenzene resin-based solid-phase extraction cartridge for analyte isolation and concentration. For analyte detection and quantitation, this method uses a high-performance liquid chromatography/ mass spectrometry system to separate the pharmaceuticals of interest from each other and from co-extracted material. Immediately following separation, the pharmaceuticals are ionized by electrospray ionization operated in the positive mode, and the positive ions produced are detected, identified, and quantified using a quadrupole mass spectrometer (Furlong and others, 2008).

Steroidal hormones and related chemicals were analyzed using NWQL schedule 2434, which consists of solidphase extraction, derivatization, and gas chromatography with tandem mass spectrometry (Foreman and others, 2012). Chemicals analyzed include 16 steroidal hormones and 4 other related compounds (trans-diethylstilbestrol, bisphenol A, cholesterol, and 3-beta-coprostanol). Briefly, a technique referred to as isotope-dilution quantification is used for this analytical 
method to improve quantitative accuracy by accounting for sample-specific procedural losses in the determined analyte concentration (Foreman and others, 2012). Deuterium- or carbon-13-labeled isotope-dilution standards (IDSs), all of which are direct or chemically similar isotopic analogs of the method analytes, are added to all environmental and quality-control and quality-assurance samples before extraction. Method analytes and IDS compounds are isolated from filtered water by solid-phase extraction onto an octadecylsilyl disk, and eluted with methanol. The extract is evaporated to dryness, reconstituted in solvent, passed through a Florisil solid-phase extraction column to remove polar organic interferences, again evaporated to dryness, and reacted to ether derivatives that are more amenable to gas chromatographic separation than the original compounds. The analysis is carried out by gas chromatography with tandem mass spectrometry using calibration standards that are derivatized concurrently with the sample extracts (Foreman and others, 2012). Chemical concentrations are quantified relative to specific IDS compounds in the sample, which directly compensate for incomplete recovery in the determined and reported analyte concentrations. Thus, reported concentrations or recoveries of the steroidal hormones and related chemicals are corrected based on recovery of the corresponding IDS compound during the quantification process (Foreman and others, 2012).

Antibiotics and other pharmaceuticals were analyzed using the LCAB method of the USGS OGRL. The LCAB method is an evolving method that was modified from a liquid chromatography/tandem mass spectrometry version of the online solid-phase extraction liquid chromatography/ mass spectrometry method in Meyer and others (2007). Briefly, water samples were analyzed for chloramphenicol, lincomycin, ormetoprim, trimethoprim, macrolide antibiotics, sulfonamide antibiotics, quinolone antibiotics, and tetracycline antibiotics, antibiotic degradation products, and the pharmaceuticals carbamazepine and ibuprofen using on online solid-phase extraction and ultra-pressure liquid chromatography/tandem mass spectrometry with electrospray ionization using multiple reaction monitoring. Samples were analyzed in positive-ion mode except for chloramphenicol and ibuprofen, which were analyzed in negative-ion mode (Meyer and others, 2007).

\section{Quality-Assurance Analyses}

Quality-assurance plans were established to evaluate laboratory and field sampling techniques, assess possible sources of contamination, and assure representative samples. All field personnel were familiar with study design and sampling protocols before field sampling or data processing to assure sample integrity.

\section{Laboratory Quality Assurance}

Results of analyses completed by the NWQL for this study are reported as estimated values, or "E" coded values, for concentrations measured above the long-term method detection level but below the laboratory reporting level (Childress and others, 1999). Nondetections are censored at the laboratory reporting level (table 2).

Laboratory quality-control samples were used to validate and interpret the environmental data. Laboratory qualitycontrol samples included laboratory blanks, reagent spikes, and surrogates. Details of USGS quality-control specifications are described in Maloney (2005). Because the NWQL reports estimated values, analytical results from laboratory and field quality-control samples must be carefully scrutinized and compared to environmental sample results to ensure that reported environmental detections are unlikely to be false positives.

Recoveries for chemicals spiked into laboratory reagent water, and surrogate compounds spiked into environmental samples, indicate the general proficiency of the laboratory methods. For laboratory reagent-water spike samples related to the sample sets for this study (table 3), most chemicals had satisfactory spike recoveries, between 50 and 120 percent (Sando and others, 2006). The chemicals on schedule 1433 with low average recoveries (less than 50 percent) were 3-tert-butyl-4-hydroxyanisole, carbaryl, cotinine, D-limonene, isopropylbenzene, and tetrachloroethene; from the schedule 2080 list, the chemicals diltiazem and sulfamethoxazole had low average recoveries. No chemicals had average recoveries greater than 120 percent. All average recoveries were within the normal recovery ranges for the analyte and method; however the recovery of the chemical isoquinoline (laboratory analytical schedule 1433) was highly variable.

Surrogates are compounds that have similar properties to the chemicals of interest, but do not interfere with quantitation of the chemicals of interest. Each analytical method had surrogate compounds added to environmental and field qualitycontrol samples before extraction to monitor method performance, as described in the references provided previously in the "Laboratory Analytical Methods" section. The compound decafluorobiphenyl (schedule 1433) was the only compound with an average surrogate spike recovery below 50 percent (table 4), and this low average recovery is within the normal recovery range for this compound (Zaugg and others, 2006).

Laboratory reagent-water blank samples were used to assess potential sample contamination attributed to laboratory processes. The laboratory-blank samples that were analyzed with the sample sets for this study were used in this analysis. A total of 31 chemicals on schedule 1433 had a detectable concentration in more than 1 laboratory-blank sample (table 5). The following chemicals that were detected in 10 or more of the 44 laboratory reagent-water blank samples were all from schedule 1433 and were, in decreasing order of detections: acetophenone, naphthalene, phenol, 4-nonylphenol (all isomers), 2-methylnaphthalene, benzophenone, beta-sitosterol, 
Table 3. Summary of chemical recoveries for laboratory reagent-water spike samples related to sample sets for this study, 2009-12.

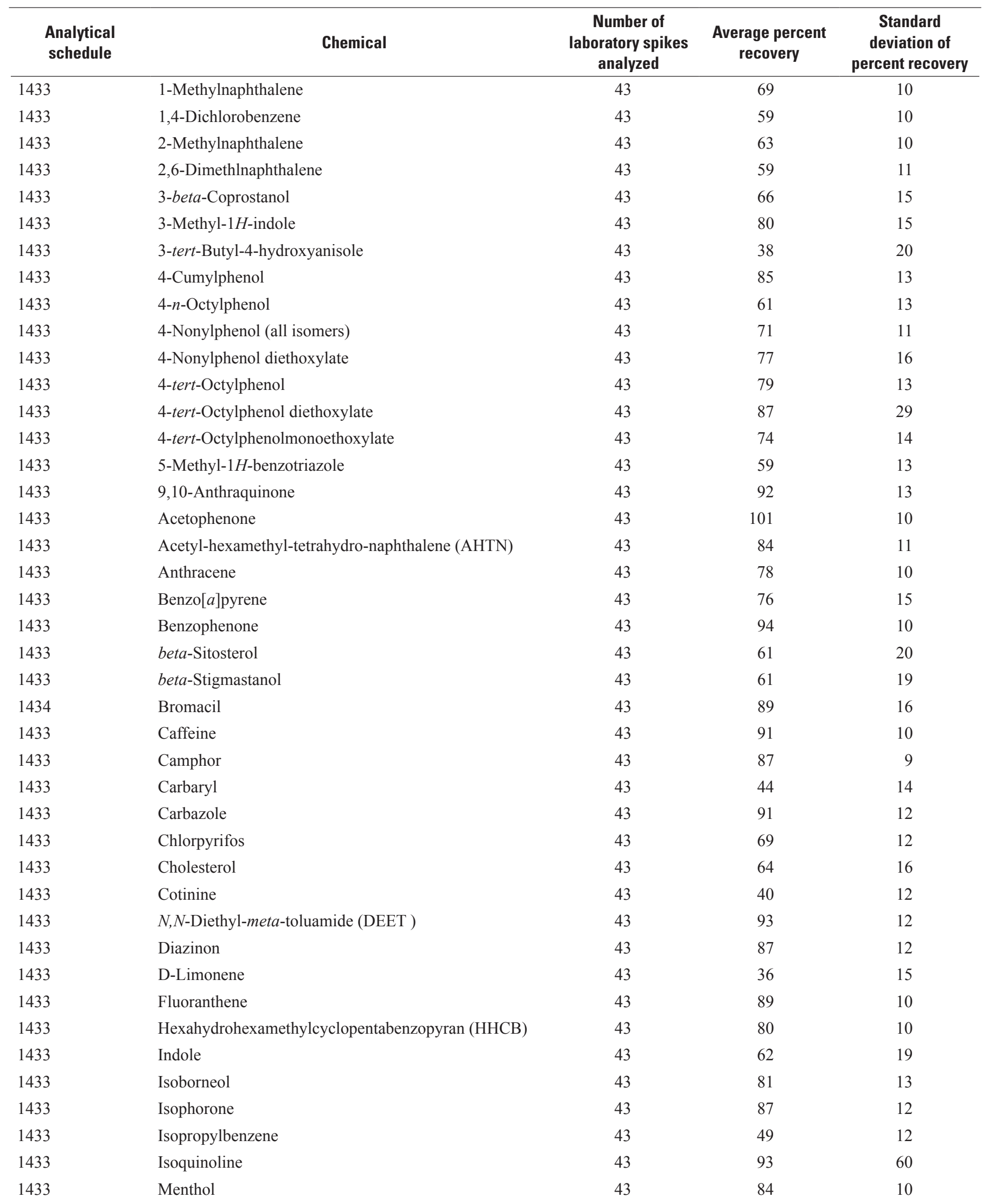


Table 3. Summary of chemical recoveries for laboratory reagent-water spike samples related to sample sets for this study, 2009-12.Continued

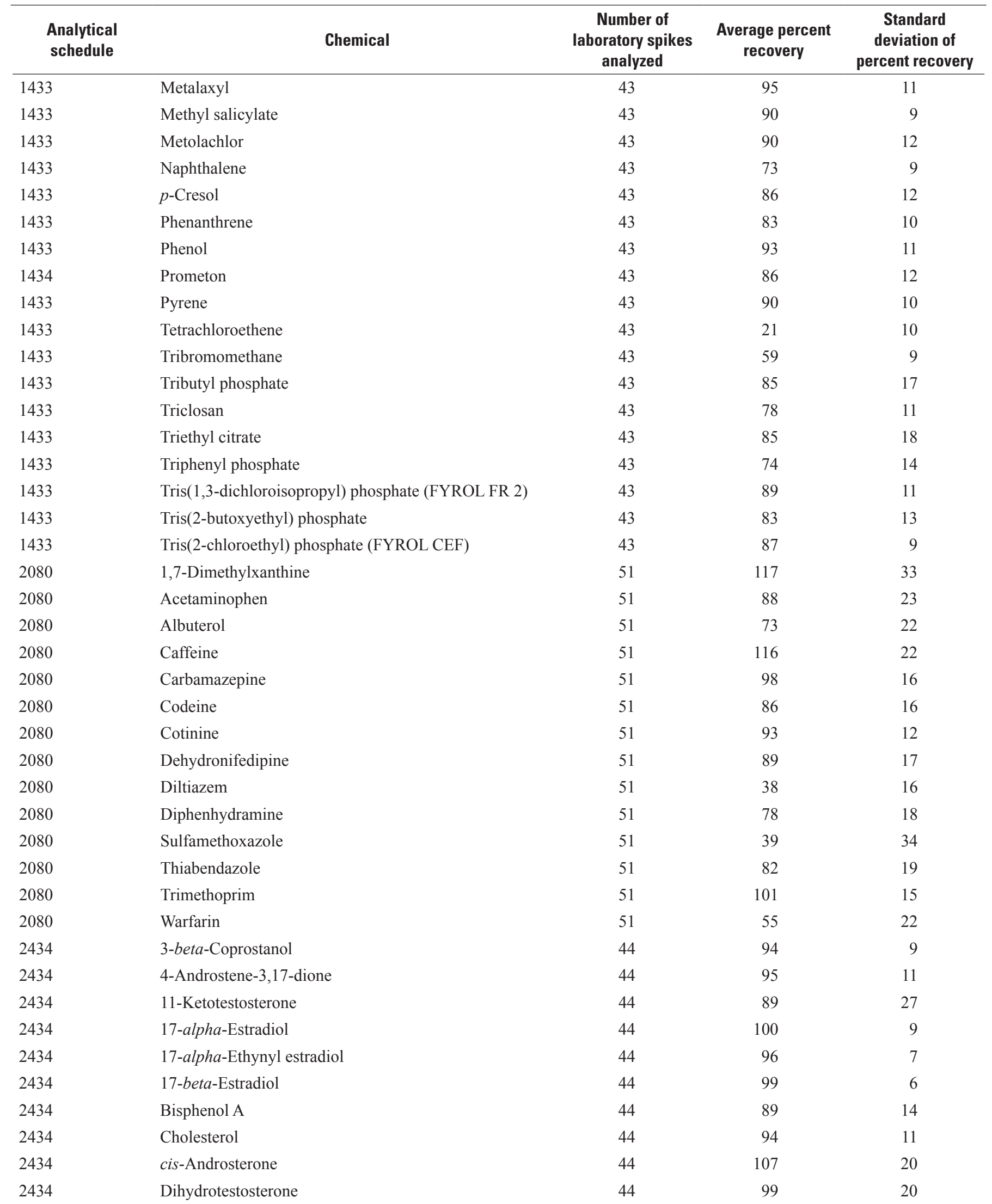


Table 3. Summary of chemical recoveries for laboratory reagent-water spike samples related to sample sets for this study, 2009-12.Continued

\begin{tabular}{|c|c|c|c|c|}
\hline $\begin{array}{l}\text { Analytical } \\
\text { schedule }\end{array}$ & Chemical & $\begin{array}{c}\text { Number of } \\
\text { laboratory spikes } \\
\text { analyzed }\end{array}$ & $\begin{array}{l}\text { Average percent } \\
\text { recovery }\end{array}$ & $\begin{array}{c}\text { Standard } \\
\text { deviation of } \\
\text { percent recovery }\end{array}$ \\
\hline 2434 & Epitestosterone & 44 & 102 & 15 \\
\hline 2434 & Equilenin & 44 & 82 & 10 \\
\hline 2434 & Equilin & 44 & 80 & 14 \\
\hline 2434 & Estriol & 44 & 88 & 23 \\
\hline 2434 & Estrone & 44 & 99 & 7 \\
\hline 2434 & Mestranol & 44 & 96 & 6 \\
\hline 2434 & Norethindrone & 44 & 97 & 8 \\
\hline 2434 & Progesterone & 44 & 94 & 27 \\
\hline 2434 & Testosterone & 44 & 102 & 16 \\
\hline 2434 & trans-Diethylstilbestrol & 44 & 88 & 7 \\
\hline LCAB & 4-Epioxytetracycline & 19 & 104 & 22 \\
\hline LCAB & 4-Epitetracycline & 19 & 103 & 22 \\
\hline LCAB & Anhydroerthromycin & 19 & 100 & 10 \\
\hline LCAB & Azithromycin & 19 & 100 & 27 \\
\hline LCAB & Carbamazepine & 19 & 85 & 16 \\
\hline LCAB & Chloramphenicol & 19 & 101 & 14 \\
\hline LCAB & Ciprofloxacin & 19 & 99 & 14 \\
\hline LCAB & Doxycycline & 19 & 103 & 23 \\
\hline LCAB & Enrofloxacin & 19 & 90 & 21 \\
\hline LCAB & Erythromycin & 19 & 120 & 16 \\
\hline LCAB & Ibuprofen & 19 & 95 & 13 \\
\hline LCAB & Lincomycin & 19 & 91 & 27 \\
\hline LCAB & Lomefloxacin & 19 & 96 & 12 \\
\hline LCAB & Norfloxacin & 19 & 94 & 24 \\
\hline LCAB & Ofloxacin & 19 & 93 & 19 \\
\hline LCAB & Ormetoprim & 19 & 94 & 19 \\
\hline LCAB & Oxytetracycline & 19 & 107 & 23 \\
\hline LCAB & Roxithromycin & 19 & 97 & 16 \\
\hline LCAB & Sarafloxacin & 19 & 93 & 19 \\
\hline LCAB & Sulfachloropyrizadine & 19 & 94 & 14 \\
\hline LCAB & Sulfadiazine & 19 & 85 & 12 \\
\hline LCAB & Sulfadimethoxine & 19 & 68 & 9 \\
\hline LCAB & Sulfamethazine & 19 & 104 & 12 \\
\hline LCAB & Sulfamethoxazole & 19 & 93 & 11 \\
\hline LCAB & Sulfathiazole & 19 & 91 & 26 \\
\hline LCAB & Tetracycline & 19 & 101 & 22 \\
\hline LCAB & Total Chlorotetracycline & 19 & 102 & 31 \\
\hline LCAB & Trimethoprim & 19 & 89 & 24 \\
\hline LCAB & Tylosin & 19 & 90 & 9 \\
\hline LCAB & Virginiamycin & 19 & 91 & 14 \\
\hline
\end{tabular}


Table 4. Summary of recoveries for surrogate compounds and isotope dilution standards analyzed in groundwater samples, 2009-12.

$\left[d\right.$, deuterium; ${ }^{13} \mathrm{C}$, carbon-13]

\begin{tabular}{llccc}
\hline $\begin{array}{c}\text { Analytical } \\
\text { schedule }\end{array}$ & \multicolumn{1}{c}{ Analyte } & $\begin{array}{c}\text { Number of } \\
\text { surrogates } \\
\text { analyzed }\end{array}$ & $\begin{array}{c}\text { Average } \\
\text { percent } \\
\text { recovery }\end{array}$ & $\begin{array}{c}\text { Standard } \\
\text { deviation } \\
\text { of percent } \\
\text { recovery }\end{array}$ \\
\hline 1433 & Caffeine- ${ }^{13} C$ & 160 & 87 & 12 \\
1433 & Decafluorobiphenyl & 160 & 48 & 9 \\
1433 & Fluoranthene- $d_{10}$ & 160 & 90 & 8 \\
2080 & Carbamazepine- $d_{10}$ & 162 & 74 & 30 \\
2080 & Ethyl nicotinate- $d_{4}$ & 162 & 78 & 18 \\
2434 & Bisphenol A- $d_{16}$ & 163 & 80 & 16 \\
2434 & Progesterone-2,3,4- ${ }^{13} C_{3}$ & 44 & 66 & 6 \\
2434 & Cholesterol- $d_{7}$ & 163 & 69 & 11 \\
2434 & Ethynylestradiol- $d_{4}$ & 163 & 81 & 12 \\
2434 & trans-Diethylstilbestrol- $d_{8}$ & 163 & 65 & 13 \\
2434 & Mestranol- $d_{4}$ & 163 & 79 & 10 \\
2434 & Estriol-2,4,16,17- $d_{4}$ & 103 & 71 & 16 \\
2434 & $16-$ Epiestriol- $d_{2}$ & 161 & 65 & 22 \\
2434 & Medroxyprogesterone- $d_{3}$ & 161 & 72 & 18 \\
2434 & Nandrolone- $d_{3}$ & 161 & 80 & 16 \\
2434 & $17-b e t a-$ Estradiol- ${ }^{13} C_{6}$ & 161 & 84 & 19 \\
2434 & Estrone- ${ }^{13} C_{6}$ & 161 & 83 & 17 \\
\hline
\end{tabular}

and $p$-cresol. All of these frequent detections in laboratoryblank samples were estimated concentrations less than the laboratory reporting level. Four chemicals from schedule 2080, 1,7-dimethylxanthine, acetaminophen, caffeine, and dehydronifedipine, were detected in more than one laboratory reagent-water blank sample, but all concentrations were much less than the laboratory reporting level. Four compounds from schedule 2434, 17-beta-estradiol, cholesterol, estriol, and trans-diethylstilbestrol, were detected in more than one laboratory reagent-water blank sample; however, only the concentration of cholesterol was greater than the laboratory reporting level. No chemicals from schedule LCAB were detected in laboratory reagent-water blanks. Chemicals that were detected in one laboratory-blank sample are not included in table 5 because these chemicals were not used in the data censoring process, which is described in the "Data Censoring Criteria" section of this report.

\section{Field Quality Assurance}

Quality-assurance samples were collected consistent with the USGS NFM (U.S. Geological Survey, variously dated). The collected field quality-assurance samples included blanks, replicates, and groundwater matrix spikes.
Potential contamination of water samples during sample collection, processing, and laboratory analysis was assessed with field equipment-blank samples. Field equipment-blank samples were prepared at selected sites before collecting the environmental sample. Field equipment-blank samples were prepared by processing high-performance liquid chromatography organic-free grade water (certified by the NWQL to be free of the chemicals of interest) through the same equipment used to collect and process field samples. Sixteen field equipment-blank samples were collected and analyzed to assess contamination introduced during sample collection, processing, and laboratory analysis for water samples. From schedule 1433,22 chemicals were detected in one or more field equipment-blank samples (table 6), and detections in field equipment-blank samples were not censored because of detections in laboratory-blank samples. Most chemicals were detected in field equipment-blank samples at concentrations less than or slightly greater than the laboratory reporting level. The chemical DEET, which is an active ingredient in insect repellant, was most frequently detected (11 of 16 field equipment blank samples). DEET and phenol were the only compounds detected in more than one field equipment-blank sample at a concentration much greater than the laboratory reporting level (table 6). Both of the elevated DEET concentrations were in blank samples collected during 2010, the first full field season. Proper field protocols regarding the use of DEET during field 
Table 5. Chemicals detected in more than one laboratory reagent-water blank sample related to sample sets for this study, 2009-12.

[LRL, laboratory reporting level; $\mu \mathrm{g} / \mathrm{L}$, micrograms per liter; E, estimated; ng/L, nanograms per liter]

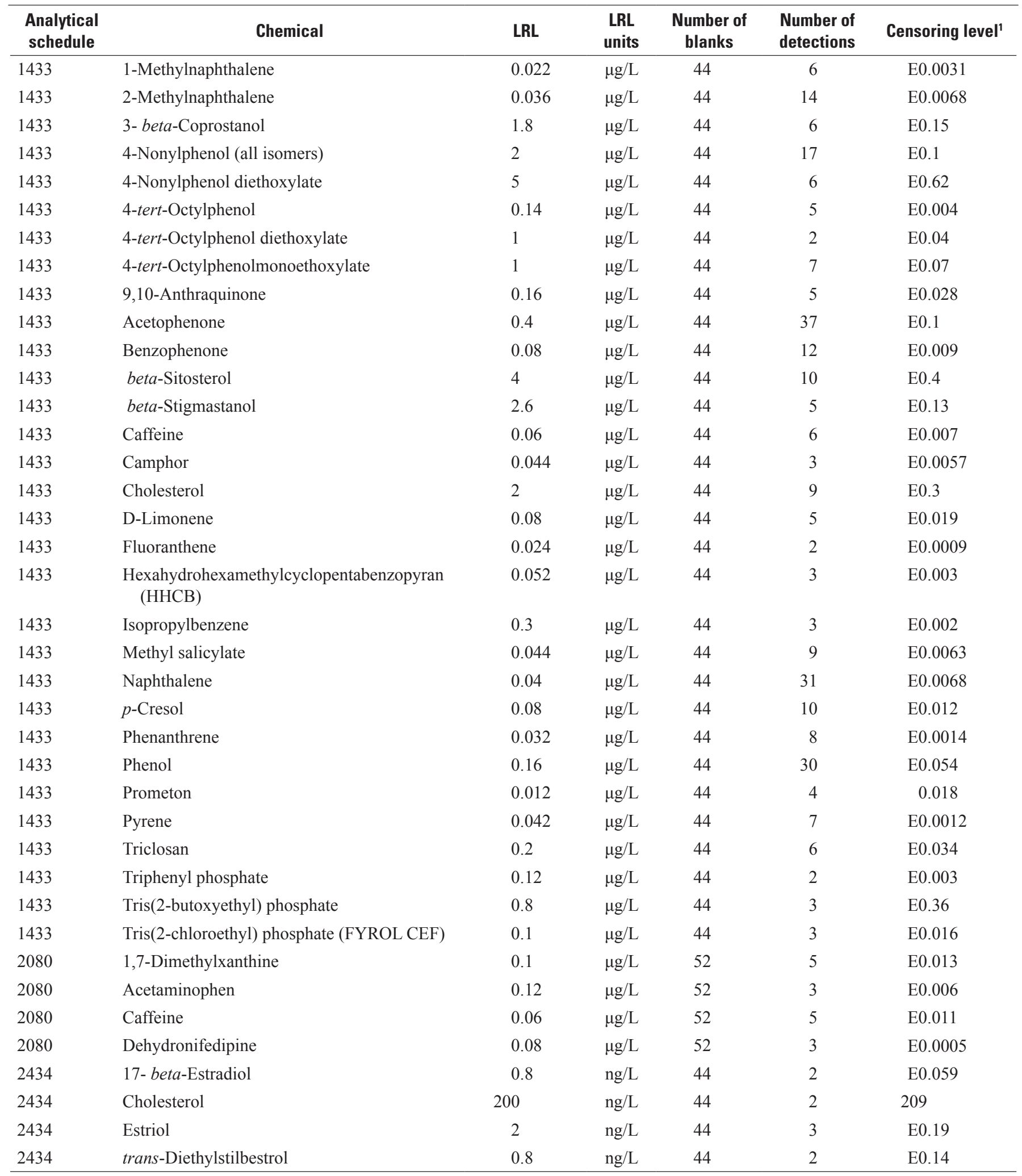

\footnotetext{
${ }^{1}$ Second highest concentration detected in laboratory-blank samples.
} 
Table 6. Concentrations of chemicals detected in field equipment-blank samples, 2009-12.

[E, estimated; LRL, laboratory reporting level; $\mu \mathrm{g} / \mathrm{L}$, micrograms per liter]

\begin{tabular}{|c|c|c|c|c|c|}
\hline $\begin{array}{l}\text { Analytical } \\
\text { schedule }\end{array}$ & Chemical & $\begin{array}{c}\text { LRL } \\
(\mu \mathrm{g} / \mathrm{L})\end{array}$ & $\begin{array}{c}\text { Number of } \\
\text { blanks }\end{array}$ & $\begin{array}{l}\text { Number of } \\
\text { detections }\end{array}$ & $\begin{array}{l}\text { Maximum } \\
\text { detection }\end{array}$ \\
\hline 1433 & 1-Methylnaphthalene & 0.022 & 16 & 6 & 0.022 \\
\hline 1433 & 2,6-Dimethlnaphthalene & 0.06 & 16 & 1 & E0.0083 \\
\hline 1433 & 2-Methylnaphthalene & 0.036 & 16 & 7 & 0.043 \\
\hline 1433 & 3-Methyl-1H-indole & 0.036 & 16 & 1 & E0.0039 \\
\hline 1433 & 4-tert-Octylphenol & 0.14 & 16 & 1 & E0.0071 \\
\hline 1433 & 9,10-Anthraquinone & 0.16 & 16 & 1 & E0.017 \\
\hline 1433 & Acetophenone & 0.4 & 16 & 1 & 0.78 \\
\hline 1433 & Anthracene & 0.01 & 16 & 2 & E0.0064 \\
\hline 1433 & Benzophenone & 0.08 & 16 & 1 & E0.021 \\
\hline 1433 & Camphor & 0.044 & 16 & 1 & E0.02 \\
\hline 1433 & Carbazole & 0.03 & 16 & 3 & 0.032 \\
\hline 1433 & Isophorone & 0.032 & 16 & 6 & E0.014 \\
\hline 1433 & Isoquinoline & 0.046 & 16 & 1 & 0.15 \\
\hline 1433 & Menthol & 0.32 & 16 & 4 & E0.054 \\
\hline 1433 & Methyl salicylate & 0.044 & 16 & 5 & E0.014 \\
\hline 1433 & $N, N$-Diethyl-meta-toluamide (DEET), 2010 samples & 0.06 & 6 & 4 & 3.8 \\
\hline 1433 & $N, N$-Diethyl-meta-toluamide (DEET), 2011-12 samples & 0.06 & 10 & 7 & 0.19 \\
\hline 1433 & Naphthalene & 0.04 & 16 & 9 & 0.19 \\
\hline 1433 & $p$-Cresol & 0.08 & 16 & 2 & E0.062 \\
\hline 1433 & Phenanthrene & 0.016 & 16 & 7 & 0.026 \\
\hline 1433 & Phenol & 0.16 & 16 & 7 & 1.1 \\
\hline 1433 & Tris(1,3-dichloroisopropyl) phosphate (FYROL FR 2) & 0.16 & 16 & 2 & E0.11 \\
\hline 1433 & Tris(2-chloroethyl) phosphate (FYROL CEF) & 0.1 & 16 & 3 & E0.063 \\
\hline 2080 & Acetaminophen & 0.12 & 16 & 1 & E0.0247 \\
\hline 2080 & Codeine & 0.046 & 16 & 1 & E0.0029 \\
\hline 2080 & Trimethoprim & 0.034 & 16 & 1 & E0.005 \\
\hline LCAB & Ormetoprim & 0.005 & 16 & 1 & 0.012 \\
\hline LCAB & Trimethoprim & 0.005 & 16 & 1 & 0.005 \\
\hline
\end{tabular}

work was clarified before sampling began in 2011. Therefore, the elevated concentrations of DEET are only relevant to the samples collected in 2009-10, and not samples from subsequent years. Three chemicals from schedule 2080, acetaminophen, codeine, and trimethoprim, were each detected in one field equipment-blank sample at concentrations much less than the laboratory reporting level. Two chemicals from the LCAB schedule, ormetoprim and trimethoprim, were detected at concentrations near the laboratory reporting level.

Replicate samples were used to quantify the variability of detection and corresponding concentrations that result from sample processing (sample splitting, filtration, and transport) and laboratory techniques. Twelve replicate samples were collected for this study. The replicate sample pairs consisted of a primary environmental field sample and a sequential replicate sample collected immediately after the environmental sample; the two samples should be nearly identical in composition. Reported concentrations, which were near or below laboratory reporting levels, were censored as described in the "Data Censoring Criteria" section of this report. No sample pairs had chemical detections in both samples that were not censored by detections in laboratory or field blanks. The concentration variability resulting from sample processing and analysis could not be evaluated.

Matrix interference was assessed by matrix spikes in groundwater samples. Groundwater matrix spike samples with associated duplicate samples were collected at six wells and shipped to the NWQL and OGRL for assessment of matrix interference. The samples were spiked at the laboratory. Most chemicals had recoveries in groundwater matrix spike samples (table 7) that were similar to recoveries for laboratory reagentwater spike samples (table 3 ). The calculated recoveries 
Table 7. Summary of field matrix spike recoveries from groundwater samples collected in Minnesota, 2009-12.

\begin{tabular}{|c|c|c|c|c|}
\hline $\begin{array}{l}\text { Analytical } \\
\text { schedule }\end{array}$ & Chemical & $\begin{array}{c}\text { Number of matrix } \\
\text { spikes analyzed }\end{array}$ & $\begin{array}{c}\text { Average } \\
\text { percent recovery }\end{array}$ & $\begin{array}{c}\text { Standard deviation of } \\
\text { percent recovery }\end{array}$ \\
\hline 1433 & 1,4-Dichlorobenzene & 10 & 66 & 8 \\
\hline 1433 & 1-Methylnaphthalene & 10 & 72 & 8 \\
\hline 1433 & 2-Methylnaphthalene & 10 & 71 & 6 \\
\hline 1433 & 2,6-Dimethlnaphthalene & 10 & 66 & 9 \\
\hline 1433 & 3-beta-Coprostanol & 10 & 76 & 15 \\
\hline 1433 & 3-Methyl-1H-indole & 10 & 82 & 19 \\
\hline 1433 & 3-tert-Butyl-4-hydroxyanisole & 9 & 36 & 25 \\
\hline 1433 & 4-Cumylphenol & 10 & 88 & 9 \\
\hline 1433 & 4-n-Octylphenol & 10 & 67 & 8 \\
\hline 1433 & 4-Nonylphenol (all isomers) & 10 & 74 & 10 \\
\hline 1433 & 4-Nonylphenol diethoxylate & 10 & 85 & 13 \\
\hline 1433 & 4-tert-Octylphenol & 10 & 85 & 12 \\
\hline 1433 & 4-tert-Octylphenol diethoxylate & 10 & 102 & 26 \\
\hline 1433 & 4-tert-Octylphenolmonoethoxylate & 10 & 82 & 9 \\
\hline 1433 & 5-Methyl-1H-benzotriazole & 8 & 69 & 16 \\
\hline 1433 & 9,10-Anthraquinone & 10 & 100 & 9 \\
\hline 1433 & Acetophenone & 10 & 100 & 9 \\
\hline 1433 & Acetyl-hexamethyl-tetrahydro-naphthalene (AHTN) & 10 & 84 & 9 \\
\hline 1433 & Anthracene & 10 & 84 & 5 \\
\hline 1433 & Benzo $[a]$ pyrene & 10 & 78 & 10 \\
\hline 1433 & Benzophenone & 10 & 100 & 6 \\
\hline 1433 & beta-Sitosterol & 10 & 69 & 16 \\
\hline 1433 & beta-Stigmastanol & 9 & 71 & 16 \\
\hline 1434 & Bromacil & 10 & 90 & 22 \\
\hline 1433 & Caffeine & 10 & 93 & 8 \\
\hline 1433 & Camphor & 10 & 90 & 8 \\
\hline 1433 & Carbaryl & 10 & 64 & 23 \\
\hline 1433 & Carbazole & 10 & 95 & 7 \\
\hline 1433 & Chlorpyrifos & 10 & 66 & 15 \\
\hline 1433 & Cholesterol & 10 & 74 & 16 \\
\hline 1433 & Cotinine & 10 & 84 & 7 \\
\hline 1433 & Diazinon & 10 & 87 & 9 \\
\hline 1433 & D-Limonene & 10 & 40 & 10 \\
\hline 1433 & Fluoranthene & 10 & 87 & 7 \\
\hline 1433 & Hexahydrohexamethylcyclopentabenzopyran (HHCB) & 10 & 84 & 11 \\
\hline 1433 & Indole & 8 & 73 & 17 \\
\hline 1433 & Isoborneol & 10 & 86 & 6 \\
\hline 1433 & Isophorone & 10 & 91 & 10 \\
\hline 1433 & Isopropylbenzene & 10 & 64 & 14 \\
\hline 1433 & Isoquinoline & 6 & 81 & 7 \\
\hline 1433 & Menthol & 10 & 86 & 8 \\
\hline 1433 & Metalaxyl & 10 & 97 & 4 \\
\hline 1433 & Methyl salicylate & 10 & 95 & 7 \\
\hline
\end{tabular}




\section{Contaminants of Emerging Concern in Ambient Groundwater in Urbanized Areas of Minnesota, 2009-12}

Table 7. Summary of field matrix spike recoveries from groundwater samples collected in Minnesota, 2009-12.-Continued

\begin{tabular}{|c|c|c|c|c|}
\hline $\begin{array}{l}\text { Analytical } \\
\text { schedule }\end{array}$ & Chemical & $\begin{array}{l}\text { Number of matrix } \\
\text { spikes analyzed }\end{array}$ & $\begin{array}{c}\text { Average } \\
\text { percent recovery }\end{array}$ & $\begin{array}{c}\text { Standard deviation of } \\
\text { percent recovery }\end{array}$ \\
\hline 1433 & Metolachlor & 10 & 89 & 7 \\
\hline 1433 & $N, N$-Diethyl-meta-toluamide (DEET) & 18 & 92 & 3 \\
\hline 1433 & Naphthalene & 10 & 85 & 17 \\
\hline 1433 & $p$-Cresol & 10 & 81 & 21 \\
\hline 1433 & Phenanthrene & 10 & 89 & 10 \\
\hline 1433 & Phenol & 10 & 97 & 11 \\
\hline 1434 & Prometon & 10 & 91 & 11 \\
\hline 1433 & Pyrene & 10 & 86 & 5 \\
\hline 1433 & Tetrachloroethene & 10 & 28 & 12 \\
\hline 1433 & Tribromomethane & 10 & 65 & 12 \\
\hline 1433 & Tributyl phosphate & 10 & 93 & 14 \\
\hline 1433 & Triclosan & 10 & 77 & 8 \\
\hline 1433 & Triethyl citrate & 10 & 92 & 30 \\
\hline 1433 & Triphenyl phosphate & 10 & 69 & 16 \\
\hline 1433 & Tris(1,3-dichloroisopropyl) phosphate (FYROL FR 2) & 10 & 90 & 6 \\
\hline 1433 & Tris(2-butoxyethyl) phosphate & 10 & 85 & 8 \\
\hline 1433 & Tris(2-chloroethyl) phosphate (FYROL CEF) & 10 & 88 & 8 \\
\hline 2080 & 1,7-Dimethylxanthine & 11 & 84 & 38 \\
\hline 2080 & Acetaminophen & 11 & 87 & 59 \\
\hline 2080 & Albuterol & 12 & 56 & 33 \\
\hline 2080 & Caffeine & 11 & 89 & 39 \\
\hline 2080 & Carbamazepine & 12 & 59 & 41 \\
\hline 2080 & Codeine & 10 & 78 & 33 \\
\hline 2080 & Cotinine & 12 & 62 & 30 \\
\hline 2080 & Dehydronifedipine & 12 & 80 & 46 \\
\hline 2080 & Diltiazem & 10 & 36 & 24 \\
\hline 2080 & Diphenhydramine & 11 & 42 & 31 \\
\hline 2080 & Sulfamethoxazole & 9 & 46 & 44 \\
\hline 2080 & Thiabendazole & 8 & 59 & 29 \\
\hline 2080 & Trimethoprim & 10 & 70 & 40 \\
\hline 2080 & Warfarin & 11 & 67 & 40 \\
\hline 2434 & 3-beta-Coprostanol & 8 & 91 & 10 \\
\hline 2434 & 4-Androstene-3,17-dione & 8 & 92 & 4 \\
\hline 2434 & 11-Ketotestosterone & 8 & 93 & 12 \\
\hline 2434 & 17-alpha-Estradiol & 8 & 101 & 7 \\
\hline 2434 & 17-alpha-Ethynyl estradiol & 8 & 91 & 2 \\
\hline 2434 & 17-beta-Estradiol & 8 & 97 & 4 \\
\hline 2434 & Bisphenol A & ${ }^{1} 6$ & 84 & 10 \\
\hline 2434 & Cholesterol & 8 & 93 & 8 \\
\hline 2434 & cis-Androsterone & 8 & 103 & 9 \\
\hline 2434 & Dihydrotestosterone & 8 & 90 & 10 \\
\hline 2434 & Epitestosterone & 8 & 96 & 7 \\
\hline 2434 & Equilenin & 8 & 81 & 10 \\
\hline
\end{tabular}


Table 7. Summary of field matrix spike recoveries from groundwater samples collected in Minnesota, 2009-12._-Continued

\begin{tabular}{|c|c|c|c|c|}
\hline $\begin{array}{l}\text { Analytical } \\
\text { schedule }\end{array}$ & Chemical & $\begin{array}{l}\text { Number of matrix } \\
\text { spikes analyzed }\end{array}$ & $\begin{array}{c}\text { Average } \\
\text { percent recovery }\end{array}$ & $\begin{array}{c}\text { Standard deviation of } \\
\text { percent recovery }\end{array}$ \\
\hline 2434 & Equilin & 8 & 93 & 28 \\
\hline 2434 & Estriol & 8 & 93 & 5 \\
\hline 2434 & Estrone & 8 & 96 & 6 \\
\hline 2434 & Mestranol & 8 & 94 & 4 \\
\hline 2434 & Norethindrone & 8 & 89 & 2 \\
\hline 2434 & Progesterone & 8 & 94 & 16 \\
\hline 2434 & Testosterone & 8 & 94 & 6 \\
\hline 2434 & trans-Diethylstilbestrol & 8 & 85 & 7 \\
\hline LCAB & 4-Epioxytetracycline & 18 & 143 & 99 \\
\hline LCAB & Anhydroerthromycin & 18 & 114 & 28 \\
\hline LCAB & Azithromycin & 18 & 109 & 54 \\
\hline LCAB & Carbamazepine & 18 & 92 & 31 \\
\hline LCAB & Chloramphenicol & 18 & 117 & 50 \\
\hline LCAB & Chlorotetracycline & 18 & 91 & 31 \\
\hline LCAB & Ciprofloxacin & 18 & 109 & 47 \\
\hline LCAB & Doxycycline & 18 & 89 & 76 \\
\hline LCAB & Enrofloxacin & 18 & 63 & 31 \\
\hline LCAB & Erythromycin & 18 & 140 & 43 \\
\hline LCAB & Ibuprofen & 18 & 107 & 57 \\
\hline LCAB & Lincomycin & 18 & 233 & 164 \\
\hline LCAB & Lomefloxacin & 18 & 63 & 33 \\
\hline LCAB & Norfloxacin & 18 & 65 & 33 \\
\hline LCAB & Ofloxacin & 18 & 58 & 29 \\
\hline LCAB & Ormetoprim & 18 & 103 & 32 \\
\hline LCAB & Oxytetracycline & 18 & 133 & 70 \\
\hline LCAB & Roxithromycin & 18 & 122 & 47 \\
\hline LCAB & Sarafloxacin & 18 & 54 & 27 \\
\hline LCAB & Sulfachloropyrizadine & 18 & 109 & 31 \\
\hline LCAB & Sulfadiazine & 18 & 91 & 34 \\
\hline LCAB & Sulfadimethoxine & 18 & 83 & 33 \\
\hline LCAB & Sulfamethazine & 18 & 120 & 35 \\
\hline LCAB & Sulfamethoxazole & 18 & 112 & 34 \\
\hline LCAB & Sulfathiazole & 18 & 83 & 23 \\
\hline LCAB & Trimethoprim & 18 & 95 & 51 \\
\hline LCAB & Tylosin & 18 & 117 & 38 \\
\hline LCAB & Virginiamycin & 18 & 212 & 252 \\
\hline
\end{tabular}

${ }^{1}$ Results from one site deleted from calculation because of high chemical concentration in associated environmental sample that greatly exceeded spiked concentration of this chemical. 
in the groundwater matrix spike samples for the chemicals DEET (schedule 1433) and bisphenol A (schedule 2434) for the sample collected on June 6, 2012, from station number 451855093195901 (map number 54, table 1, fig. 2) were not included in the average matrix spike recovery calculations in table 7 because these two chemicals were detected in the associated environmental sample at concentrations much greater than the laboratory reporting level and the spiked concentration. These high concentrations in the environmental sample make spike recovery calculations for the associated groundwater spike sample highly uncertain. In contrast to the groundwater matrix spike results, the laboratory surrogate spikes in these environmental samples had normal recoveries, providing additional evidence that the recovery calculations for the groundwater matrix spike are erroneous for these samples with high environmental concentrations of DEET and bisphenol A. From schedule LCAB, the compounds 4-epioxytetracycline, lincomycin, and virginiamycin had average recoveries of more than 140 percent in the field matrix spike samples (table 7). The chemicals 4-epioxytetracycline and virginiamycin were not detected in any environmental samples, whereas lincomycin was detected in four environmental samples. Reported concentrations for lincomycin in environmental samples that are less than 10 times greater than the laboratory reporting level were flagged with an "E" to indicate that these reported concentrations are estimated (potential positive bias) based on the high matrix spike recoveries. In addition, the fluoroquinolones (ciprofloxacin, enrofloxacin, lomefloxacin, norfloxacin, ofloxacin, and sarafloxacin) were not recovered in 3 of the 18 groundwater matrix spike samples for the LCAB schedule, and in 1 of these 3 samples, the macrolides (azithromycin, erythromycin, erythromycin- $\mathrm{H}_{2} \mathrm{O}$, roxithromycin, tylosin, and virginiamycin) and 3 other antibiotics (epi-chlorotetracycline, epi-iso-chlorotetracycline, and iso-chlorotetracycline) also were not recovered. These groundwater matrix spike results indicate that some of the groundwater matrices were rapidly sorbing, chelating, or degrading selected chemicals. All of these processes would result in a reduction of the measured chemical concentration in an environmental sample, if the compound had been present in the sample initially. These processes, therefore, introduce potential negative bias for detecting and reporting these chemicals.

\section{Data Censoring Criteria}

The USGS Office of Water Quality issued technical guidance to the NWQL in 2011 for "flagging" environmental analytical results that may have been affected by laboratory contamination (U.S. Geological Survey Office of Water Quality, 2011). In this report, consistent with the technical guidance from the USGS Office of Water Quality, concentrations in environmental samples that are less than 10 times greater than the second highest concentration detected in laboratoryblank samples (table 5, Censoring level) or the maximum concentration in field-blank samples (table 6), whichever is larger, were considered potentially affected by laboratory or field procedure contamination. Because of the large number of laboratory-blank samples, there is 90-percent confidence that 95 percent of detections will be less than the censoring level. Reported environmental concentrations that were less than 10 times greater than the criteria above were flagged with a " $v$ " code and were not counted as environmental detections for data analyses in this report. The results for DEET were censored in two groups: 2010 data as one group compared to field blank results for only 2010, and 2011-12 results grouped together and compared to all field blank results for 2011-12. All other chemicals were censored together using all field blanks for 2010-12. All analytical results for the environmental samples are provided in the appendix tables (tables 1-1 through 1-5, Microsoft ${ }^{\circledR}$ Excel spreadsheet) as reported in the National Water Information System database (U.S. Geological Survey, 2013); however, sample results potentially affected by laboratory or field blank contamination (potential false positives) were flagged as such with a " $\mathrm{v}$ " code in the supplemental tables in this report and were not counted as detections in the data analyses.

The sensitivity of the various analytical methods used to analyze CECs for this study can affect the calculated detection frequencies of the chemicals. The CECs with low laboratory reporting levels likely would be detected more frequently that those with high laboratory reporting levels. Laboratory reporting levels for the CECs analyzed for this study range from $0.0008 \mu \mathrm{g} / \mathrm{L}$ (0.8 nanograms per liter, ng/L) to $5 \mu \mathrm{g} / \mathrm{L}$ (table 2). No additional data censoring was applied to account for the different laboratory reporting levels among the CECs.

\section{Presence of Chemicals of Emerging Concern in Ambient Groundwater}

Physical properties and concentrations of CECs in samples of ambient groundwater collected from wells in urbanized areas of Minnesota during 2009-12 are presented in this section of the report. Concentrations of detected CECs are compared to health-based water-quality standards and benchmarks, and potential environmental implications are described.

\section{Physical Properties}

Physical properties (dissolved oxygen, $\mathrm{pH}$, specific conductance, and water temperature) were collected in the field using a water-quality multiparameter meter sonde at all wells before collecting water samples for analyses of CECs. These field measurements are summarized in table 8 , and detailed results are provided in appendix table 1-1. Dissolved oxygen (DO) concentrations in drinking water wells screened in glacial aquifers averaged 1.77 milligrams per liter $(\mathrm{mg} / \mathrm{L})$, which is lower than the average DO concentration of $5.22 \mathrm{mg} / \mathrm{L}$ for monitoring wells screened in glacial aquifers. Wells completed 
Table 8. Summary of well depths and physical properties in unfiltered groundwater, Minnesota, 2009-12.

$\left[\mathrm{mg} / \mathrm{L}\right.$, milligrams per liter; $\mu \mathrm{S} / \mathrm{cm}$, microsiemens per centimeter at 25 degrees Celsius; ${ }^{\circ} \mathrm{C}$, degrees Celsius; $\mathrm{ft}$ BGS, feet below ground surface]

\begin{tabular}{|c|c|c|c|c|c|c|c|}
\hline Well description & Statistic & $\begin{array}{c}\text { Number of } \\
\text { wells }\end{array}$ & $\begin{array}{l}\text { Dissolved } \\
\text { oxygen } \\
\text { (mg/L) }\end{array}$ & $\begin{array}{c}\text { pH } \\
\text { (standard } \\
\text { units) }\end{array}$ & $\begin{array}{c}\text { Specific } \\
\text { conductance } \\
(\mu \mathrm{S} / \mathrm{cm})\end{array}$ & $\begin{array}{c}\text { Water } \\
\text { temperature } \\
\left({ }^{\circ} \mathrm{C}\right)\end{array}$ & $\begin{array}{l}\text { Well depth } \\
\text { (ft BGS) }\end{array}$ \\
\hline \multicolumn{8}{|c|}{ Glacial aquifers } \\
\hline \multirow[t]{3}{*}{ All glacial aquifer wells } & Average & 105 & 4.63 & 7.01 & 719 & 9.89 & 30 \\
\hline & Standard deviation & 105 & 3.80 & 0.78 & 619 & 1.73 & 20 \\
\hline & Minimum & 105 & 0 & 5.02 & 57 & 6.29 & 9 \\
\hline Drinking water wells ${ }^{1}$ & Average & 17 & 1.77 & 7.03 & 1,052 & 10.31 & 61 \\
\hline Monitoring wells & Average & 88 & 5.22 & 7.00 & 650 & 9.80 & 23 \\
\hline \multicolumn{8}{|c|}{ Bedrock aquifers } \\
\hline All bedrock aquifer wells & Average & 13 & 4.42 & 7.20 & 659 & 10.92 & 188 \\
\hline Drinking water wells ${ }^{2}$ & Average & 11 & 4.36 & 7.25 & 671 & 10.86 & 209 \\
\hline Monitoring wells & Average & 2 & 4.77 & 6.94 & 594 & 11.24 & 70 \\
\hline \multicolumn{8}{|c|}{ All wells combined } \\
\hline \multirow[t]{4}{*}{ All wells } & Average & 118 & 4.60 & 7.03 & 713 & 10.00 & 47 \\
\hline & Standard deviation & 118 & 3.83 & 0.74 & 589 & 1.68 & 59 \\
\hline & Minimum & 118 & 0 & 5.02 & 57 & 6.29 & 9 \\
\hline & Maximum & 118 & 11.65 & 9.57 & 4,011 & 14.43 & 285 \\
\hline
\end{tabular}

${ }^{1}$ All domestic wells.

${ }^{2}$ Ten domestic wells and one public water system well.

in bedrock aquifers also had a higher average DO concentration $(4.42 \mathrm{mg} / \mathrm{L})$ than drinking water wells screened in glacial aquifers. Most measured $\mathrm{pH}$ values were near neutral, with an average $\mathrm{pH}$ value of 7.03 standard units (standard deviation of 0.74 standard units) for all well types screened in either glacial or bedrock aquifers; $\mathrm{pH}$ values ranged from 5.02 to 9.57 standard units. Measured water temperature values ranged from 6.29 to $14.43{ }^{\circ} \mathrm{C}$; the average groundwater temperature was $10.00^{\circ} \mathrm{C}$, with a standard deviation of $1.68^{\circ} \mathrm{C}$. For wells screened in glacial aquifers, the specific conductance for drinking water wells averaged 1,052 microsiemens per centimeter at $25^{\circ} \mathrm{C}(\mu \mathrm{S} / \mathrm{cm})$, compared to an average specific conductance of $650 \mu \mathrm{S} / \mathrm{cm}$ for monitoring wells. For wells completed in bedrock aquifers, the average specific conductance was $659 \mu \mathrm{S} / \mathrm{cm}$. Measurements of groundwater physical properties for this study are similar to those for a statewide groundwater study completed by the MPCA in the 1990s (Minnesota Pollution Control Agency, 1998).

Specific conductance is a measure of the concentration of dissolved solids in water, and higher specific conductance measurements indicate that the groundwater being measured had a relatively longer contact time with the aquifer minerals allowing for more chemical changes to take place (Winter and others, 1998). Similarly, lower DO concentrations indicate relatively longer residence time and isolation from atmospheric conditions. In this study, the specific conductance was higher and the DO concentration was lower for drinking water wells screened in the glacial aquifer than for monitoring wells screened in the glacial aquifer and for wells completed in bedrock aquifers, even though the sampled wells in the glacial aquifers generally were shallower than the sampled wells in the bedrock aquifers. These results indicate a relatively longer flow path of water to the glacial aquifer drinking water wells compared to other wells sampled in this study.

\section{Chemicals of Emerging Concern in Groundwater}

During this study, 38 of 127 CECs analyzed were detected among all water samples collected (table 9). Three of the detected CECs (carbamazepine, cotinine, and sulfamethoxazole), however, were analyzed using two different analytical methods (2080 and 1433 or LCAB), so 35 distinct chemicals were detected. The number of detections of CECs in individual water samples ranged from 0 to 10 (table 10, tables 1-2 through 1-5; Erickson, 2012). The three wells in proximity 
Table 9. Detected chemicals and maximum concentration of contaminants of emerging concern analyzed in groundwater samples, Minnesota, 2009-12.

$[\mu \mathrm{g} / \mathrm{L}$, micrograms per liter; E, estimated; ng/L, nanograms per liter]

\begin{tabular}{|c|c|c|c|c|c|}
\hline $\begin{array}{l}\text { Analytical } \\
\text { schedule }\end{array}$ & Analyte & $\begin{array}{l}\text { Number of } \\
\text { detections }\end{array}$ & $\begin{array}{l}\text { Maximum } \\
\text { detection }\end{array}$ & $\begin{array}{l}\text { Laboratory } \\
\text { reporting level }\end{array}$ & Unit \\
\hline 1433 & 1,4-Dichlorobenzene & 3 & 0.18 & 0.04 & $\mu \mathrm{g} / \mathrm{L}$ \\
\hline 1433 & 3-Methyl-1H-indole & 1 & 0.087 & 0.036 & $\mu \mathrm{g} / \mathrm{L}$ \\
\hline 1433 & 4-Cumylphenol & 2 & E0.14 & 0.06 & $\mu \mathrm{g} / \mathrm{L}$ \\
\hline 1433 & 4-tert-Octylphenol & 2 & 0.19 & 0.14 & $\mu \mathrm{g} / \mathrm{L}$ \\
\hline 1433 & 5-Methyl-1H-benzotriazole & 1 & 0.16 & 1.2 & $\mu \mathrm{g} / \mathrm{L}$ \\
\hline 1434 & Bromacil & 2 & 0.50 & 0.36 & $\mu \mathrm{g} / \mathrm{L}$ \\
\hline 1433 & Caffeine & 1 & 0.10 & 0.06 & $\mu \mathrm{g} / \mathrm{L}$ \\
\hline 1433 & Camphor & 2 & 0.890 & 0.044 & $\mu \mathrm{g} / \mathrm{L}$ \\
\hline 1433 & Carbazole & 2 & 2.9 & 0.03 & $\mu \mathrm{g} / \mathrm{L}$ \\
\hline 1433 & Cotinine & 3 & 0.030 & 0.8 & $\mu \mathrm{g} / \mathrm{L}$ \\
\hline 1433 & $N, N$-Diethyl-meta-toluamide (DEET), 2011-12 & 1 & 7.9 & 0.06 & $\mu \mathrm{g} / \mathrm{L}$ \\
\hline 1433 & Fluoranthene & 2 & 0.034 & 0.024 & $\mu \mathrm{g} / \mathrm{L}$ \\
\hline 1433 & Tris(2-chloroethyl) phosphate (FYROL CEF) & 2 & 1.4 & 0.1 & $\mu \mathrm{g} / \mathrm{L}$ \\
\hline 1433 & НHCB & 1 & 0.057 & 0.052 & $\mu \mathrm{g} / \mathrm{L}$ \\
\hline 1433 & Indole & 1 & 0.24 & 0.08 & $\mu \mathrm{g} / \mathrm{L}$ \\
\hline 1433 & Isopropylbenzene & 3 & 0.83 & 0.3 & $\mu \mathrm{g} / \mathrm{L}$ \\
\hline 1433 & Metolachlor & 3 & E0.022 & 0.028 & $\mu \mathrm{g} / \mathrm{L}$ \\
\hline 1433 & $p$-Cresol & 1 & 2.9 & 0.08 & $\mu \mathrm{g} / \mathrm{L}$ \\
\hline 1433 & Pyrene & 3 & 0.044 & 0.042 & $\mu \mathrm{g} / \mathrm{L}$ \\
\hline 1433 & Tetrachloroethene & 1 & 0.18 & 0.12 & $\mu \mathrm{g} / \mathrm{L}$ \\
\hline 1433 & Tributyl phosphate & 5 & 0.98 & 0.16 & $\mu \mathrm{g} / \mathrm{L}$ \\
\hline 1433 & Triethyl citrate & 1 & E0.01 & 0.16 & $\mu \mathrm{g} / \mathrm{L}$ \\
\hline 1433 & Triphenyl phosphate & 1 & E0.037 & 0.12 & $\mu \mathrm{g} / \mathrm{L}$ \\
\hline 2080 & Acetaminophen & 1 & 0.75 & 0.12 & $\mu \mathrm{g} / \mathrm{L}$ \\
\hline 2080 & Carbamazepine & 2 & 0.122 & 0.06 & $\mu \mathrm{g} / \mathrm{L}$ \\
\hline 2080 & Cotinine & 3 & 0.030 & 0.038 & $\mu \mathrm{g} / \mathrm{L}$ \\
\hline 2080 & Diphenhydramine & 5 & 0.016 & 0.058 & $\mu \mathrm{g} / \mathrm{L}$ \\
\hline 2080 & Sulfamethoxazole & ${ }^{17}$ & E0.1126 & 0.091 & $\mu \mathrm{g} / \mathrm{L}$ \\
\hline 2434 & 3-beta-Coprostanol & 1 & 249 & 200 & $\mathrm{ng} / \mathrm{L}$ \\
\hline 2434 & Bisphenol A & 6 & 4,411 & 100 & $\mathrm{ng} / \mathrm{L}$ \\
\hline 2434 & cis-Androsterone & 1 & 2.04 & 0.8 & $\mathrm{ng} / \mathrm{L}$ \\
\hline 2434 & Mestranol & 1 & 0.71 & 0.8 & $\mathrm{ng} / \mathrm{L}$ \\
\hline LCAB & Azithromycin & 5 & 0.023 & 0.005 & $\mu \mathrm{g} / \mathrm{L}$ \\
\hline LCAB & Carbamazepine & 2 & 0.122 & 0.005 & $\mu \mathrm{g} / \mathrm{L}$ \\
\hline LCAB & Lincomycin & 4 & 0.110 & 0.005 & $\mu \mathrm{g} / \mathrm{L}$ \\
\hline LCAB & Sulfadiazine & 2 & 0.021 & 0.005 & $\mu \mathrm{g} / \mathrm{L}$ \\
\hline LCAB & Sulfamethazine & 3 & 0.040 & 0.005 & $\mu \mathrm{g} / \mathrm{L}$ \\
\hline LCAB & Sulfamethoxazole & ${ }^{1} 13$ & 0.171 & 0.005 & $\mu \mathrm{g} / \mathrm{L}$ \\
\hline
\end{tabular}

${ }^{1}$ Sulfamethoxazole detected by one or both analytical methods in 14 samples. 
Table 10. Detection frequency of contaminants of emerging concern by use of water, aquifer type, and land use or monitoring type, Minnesota, 2009-12.

\begin{tabular}{|c|c|c|c|c|c|c|}
\hline Well description & $\begin{array}{c}\text { Number of } \\
\text { wells }\end{array}$ & $\begin{array}{c}\text { Number of } \\
\text { samples }\end{array}$ & $\begin{array}{l}\text { Number of } \\
\text { samples with } \\
\text { detections }\end{array}$ & $\begin{array}{l}\text { Percentage of } \\
\text { samples with } \\
\text { detections }\end{array}$ & $\begin{array}{l}\text { Number of } \\
\text { detections }\end{array}$ & $\begin{array}{c}\text { Maximum number of } \\
\text { detections } \\
\text { in one well }\end{array}$ \\
\hline \multicolumn{7}{|c|}{ Use of water } \\
\hline Domestic/public (drinking water) ${ }^{1}$ & 28 & 30 & 16 & 53 & 24 & 5 \\
\hline Monitoring & 90 & 93 & 27 & 29 & 76 & 10 \\
\hline \multicolumn{7}{|c|}{ Aquifer type } \\
\hline Glacial & 105 & 110 & 35 & 32 & 88 & 10 \\
\hline Bedrock & 13 & 13 & 8 & 62 & 12 & 5 \\
\hline \multicolumn{7}{|c|}{ Land use or monitoring type } \\
\hline Commercial/industrial & 13 & 13 & 4 & 31 & 8 & 3 \\
\hline Deep well & 33 & 34 & 16 & 47 & 22 & 5 \\
\hline Landfill monitoring & 3 & 5 & 5 & 100 & 34 & 10 \\
\hline Septic residential & 30 & 31 & 7 & 23 & 16 & 4 \\
\hline Sewered residential & 24 & 25 & 8 & 32 & 16 & 5 \\
\hline Undeveloped & 15 & 15 & 3 & 20 & 4 & 2 \\
\hline \multicolumn{7}{|c|}{ All wells } \\
\hline All wells & 118 & 123 & 43 & 35 & 100 & 10 \\
\hline
\end{tabular}

${ }^{1}$ One public system well and 27 domestic wells.

to landfills had the most CEC detections (table 10). One or more CECs were detected in a total of 43 samples (35 percent) (table 10); no CECs were detected in 80 samples.

The antibiotic sulfamethoxazole was the most frequently detected CEC, detected in a total of 14 of 123 samples (11.4 percent) by one or both analytical methods that include sulfamethoxazole as an analyte (table 9; table 1-3 and table 1-5). Other CECs detected in more than one sample were azithromycin, carbamazepine, diphenhydramine, lincomycin, sulfadiazine, and sulfamethazine (human and animal-use pharmaceuticals); camphor (flavor, fragrance); 4-cumylphenol and 4-tert-octylphenol (nonionic detergent metabolites); bromacil (herbicide active ingredient); carbazole and metolachlor (pesticide active ingredients); tris(2-chloroethyl) phosphate (plasticizer and flame retardant); cotinine (nicotine metabolite); bisphenol A (plastic and resin component); fluoranthene and pyrene (asphalt components, combustion products), 1,4-dichlorobenzene (moth repellant); tributyl phosphate (corrosion inhibitor); and isopropylbenzene (fuel and paint thinner component) (fig. 3; table 2; tables 1-2 through 1-5; Erickson, 2012). The hormone or hormone metabolites cis-androsterone and mestranol were each detected in one sample (table 1-4). Also detected in one sample each were a fecal indicator and a fecal stench component, 3-beta-coprostanol and 3-methyl$1 H$-indole, respectively. Chemicals detected in one sample and found in products used for ingestion or topical use were acetaminophen, caffeine, DEET, hexahydrohexamethylcyclopentabenzopyran (HHCB), and triethyl citrate. The chemicals indole, 5-methyl-1H-benzotriazole, $p$-cresol, tetrachloroethene, and triphenyl phosphate, which are components of different types of industrial products, also were each detected in one sample. As noted previously in the "Data Censoring Criteria" section, concentration data were not censored to account for differences in the laboratory reporting levels for the CECs (table 2); thus the detection frequencies presented in this report are biased towards CECs with low laboratory reporting levels.

In a June 2012 sample, DEET was detected at the highest concentration of any CEC during the study at 7.9 micrograms per liter $(\mu \mathrm{g} / \mathrm{L})$, at site 451855093195901 (map number 54, fig. 2, table 1), which is in proximity to a closed landfill. Bisphenol A was the second most frequently detected CEC, detected in 6 of 123 samples. Site 451855093195901 (map number 54 , fig. 2, table 1 ), which is in proximity to a closed landfill, had the most CECs detected (10 chemicals) in one sample. The five samples from the three wells in proximity to closed landfills (denoted as "Landfill monitoring" in table 1) had 34 of the 100 total CEC detections, and these samples had the highest frequency of CEC detection (table 10; tables 1-2 through 1-5; Erickson, 2012). Deep wells and wells located in sewered residential land use areas had higher percentages of samples with CEC detections than wells located in undeveloped and septic residential land uses (table 10). Wells classified as deep were primarily bedrock drinking water wells. Samples from wells used as drinking water sources had a higher percentage of CEC detections than did samples from monitoring wells; however, only 24 percent of the wells sampled were drinking water wells. The spatial distribution of CEC detections in sampled wells is shown in figure 4. 


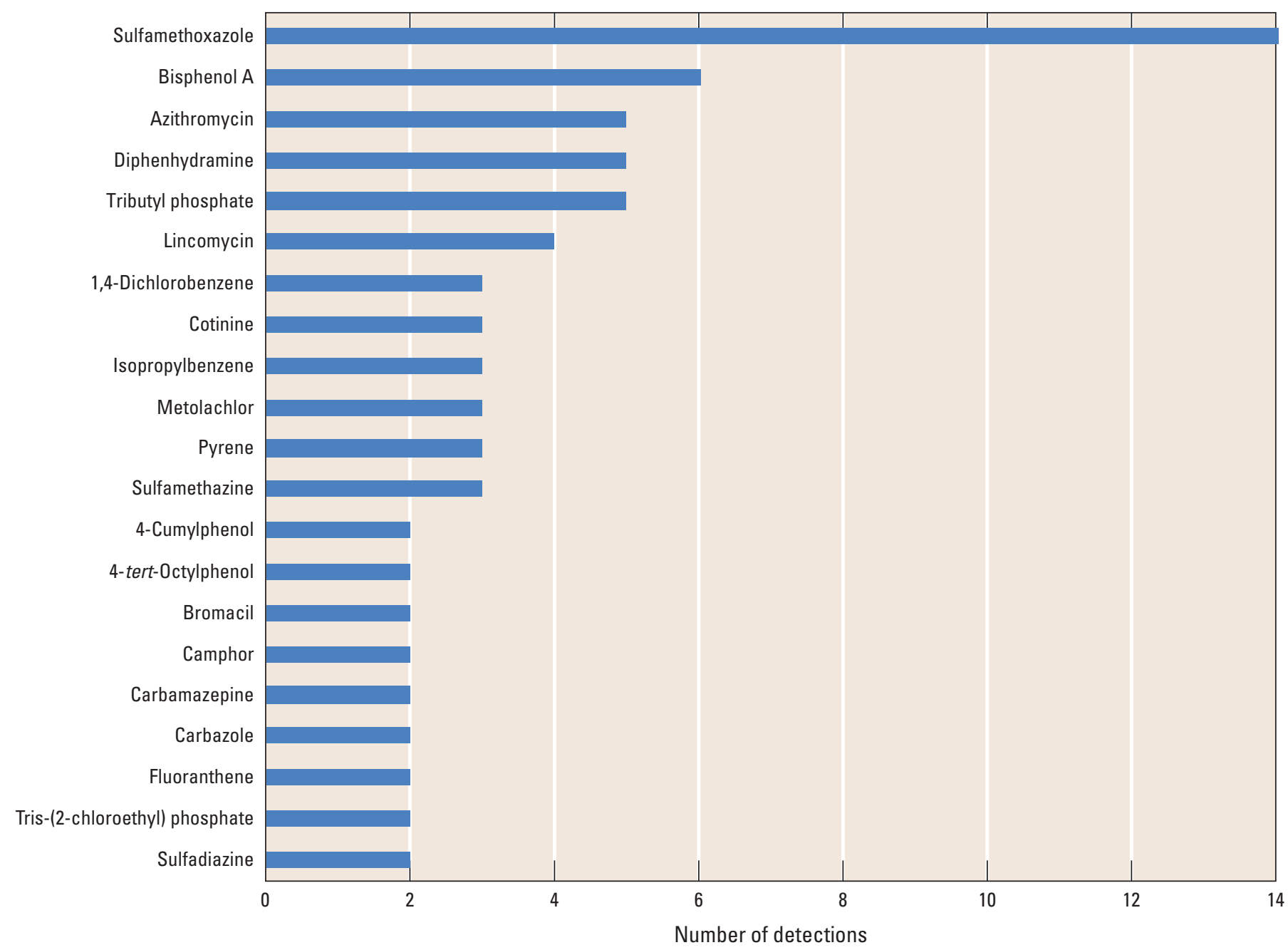

Figure 3. Number of detections of selected contaminants of emerging concern in groundwater samples from urbanized areas of Minnesota, 2009-12.

\section{Comparison of Concentrations with Health- Based Water-Quality Standards and Benchmarks}

Of the 127 chemicals analyzed for this study, only 28 have established enforceable or non-enforceable health-based water-quality standards or benchmarks (table 11). The two types of enforceable water-quality standards are Minnesota Department of Health (MDH) Health Risk Limits (HRLs; Minnesota Department of Health, 2013) and U.S. Environmental Protection Agency (EPA) Maximum Contaminant Levels (MCLs) (U.S. Environmental Protection Agency, 2013). The non-enforceable water-quality standards are MDH Health-Based Values (HBVs) (Minnesota Department of Health, 2013) and USGS Health-Based Screening Levels (HBSLs) (Toccalino and others, 2012).

The HRLs are enforceable, promulgated guidance values adopted through a formal rulemaking process authorized in the State of Minnesota 1989 Groundwater Protection Act
(State of Minnesota, 2013). The HBVs are non-enforceable but are developed as interim guidance until MDH can adopt an HRL through rulemaking. The HBVs meet the same data requirements as HRLs. If a contaminant has been detected in groundwater, then HBVs for water may become HRLs at the time that MDH next amends the Health Risk Limits for Groundwater rule (Minnesota Department of Health, 2013). The MCLs are the EPA enforceable standards that apply to public water systems, which protect public health by limiting the levels of contaminants in drinking water. The HBSLs are non-enforceable benchmark concentrations of unregulated contaminants in water that may be of potential concern for human health, if exceeded. The HBSLs were developed by the USGS in collaboration with the EPA and others (Toccalino and others, 2012).

Fourteen of the 35 detected compounds have established health-based water-quality standards, whereas 21 detected compounds have no established standard or benchmark. All detections in this study were less than health-based waterquality standards. Although most detections were well below 


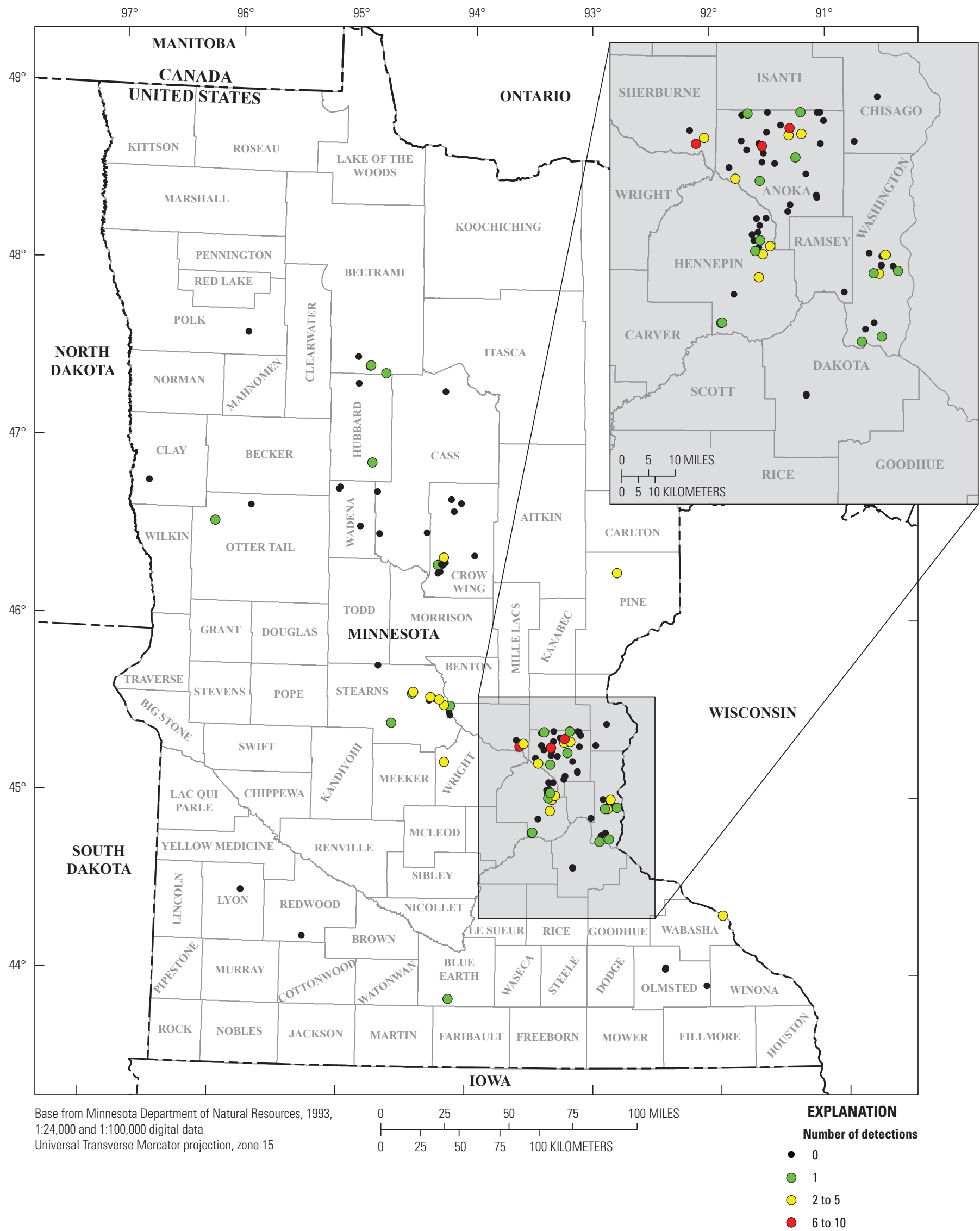

Figure 4. Sampled well locations and number of detection of contaminants of emerging concern in groundwater samples from urbanized areas of Minnesota, 2009-12. 
Table 11. Health-based water quality standards and benchmarks ${ }^{1}$ for chemicals analyzed for this study.

[ $\mu \mathrm{g} / \mathrm{L}$, micrograms per liter; MDH, Minnesota Department of Health; HRL, Health Risk Limit, subscript denotes year when value was established²; USGS, U.S. Geological Survey; HBSL, Health-Based Screening Leveli3; HBV, Health-Based Value, subscript denotes year when value was established²; EPA, U.S. Environmental Protection Agency; MCL, Maximum Contaminant Level ${ }^{4}$ ]

\begin{tabular}{|c|c|c|c|}
\hline Chemical & $\begin{array}{c}\text { Standard or benchmark } \\
(\mu \mathrm{g} / \mathrm{L})\end{array}$ & Standard source & $\begin{array}{l}\text { Detected in this } \\
\text { study? }\end{array}$ \\
\hline 1,4-Dichlorobenzene & 10 & MDH HRL $_{1994}$ & Yes \\
\hline 2-Methylnaphthalene & 30 & USGS HBSL & No \\
\hline Acetaminophen & 200 & $\mathrm{MDH} \mathrm{HBV}_{2011}$ & Yes \\
\hline Acetophenone & 700 & USGS HBSL & No \\
\hline Acetyl-hexamethyl-tetrahydro-naphthalene (AHTN) & 20 & MDH HRL $_{2013}$ & No \\
\hline Anthracene & 2000 & MDH HRL $_{1993}$ & No \\
\hline Benzo $[a]$ pyrene & 0.2 & EPA MCL & No \\
\hline Benzo $[a]$ pyrene & 0.06 & $\mathrm{MDH} \mathrm{HBV}_{2012}$ & No \\
\hline Bisphenol A & 20 & $\mathrm{MDH} \mathrm{HBV}_{2014}$ & Yes \\
\hline Carbamazepine & 40 & $\mathrm{MDH} \mathrm{HRL}_{2013}$ & Yes \\
\hline Carbaryl & 40 & USGS HBSL & No \\
\hline Chlorpyrifos & 0.6 & $\mathrm{MDH} \mathrm{HBV}_{2013}$ & No \\
\hline$N, N$-Diethyl-meta-toluamide (DEET) & 200 & MDH HRL $_{2013}$ & Yes \\
\hline Diazinon & 1 & USGS HBSL & No \\
\hline Fluoranthene & 300 & MDH HRL $_{1993}$ & Yes \\
\hline Isophorone & 100 & MDH HRL $_{1993}$ & No \\
\hline Isopropyl benzene (cumene) & 300 & $\mathrm{MDH} \mathrm{HRL}_{1993}$ & Yes \\
\hline Metalaxyl & 500 & USGS HBSL & No \\
\hline Methanol & 3000 & MDH HRL $_{1994}$ & No \\
\hline Metolachlor & 300 & MDH HRL $_{2011}$ & Yes \\
\hline Naphthalene & 70 & $\mathrm{MDH} \mathrm{HRL}_{2013}$ & No \\
\hline$p$-Cresol & 3 & MDH HRL $_{1994}$ & Yes \\
\hline Phenol & 2000 & USGS HBSL & No \\
\hline Pyrene & 200 & $\mathrm{MDH}_{\mathrm{HRL}} \mathrm{H}_{1993}$ & Yes \\
\hline Sulfamethazine & 100 & $\mathrm{MDH} \mathrm{HBV}_{2013}$ & Yes \\
\hline Sulfamethoxazole & 100 & MDH RAA $_{2013}$ & Yes \\
\hline Tetrachloroethene & 5 & EPA MCL & Yes \\
\hline Tris(2-chloroethyl) phosphate (FYROL CEF) & 5 & $\mathrm{MDH} \mathrm{HRL}_{2013}$ & Yes \\
\hline Triclosan & 50 & $\mathrm{MDH} \mathrm{HBV}_{2014}$ & No \\
\hline
\end{tabular}

${ }^{1}$ Twenty-one analytes detected in this study do not have established drinking water or other water-quality targets.

${ }^{2}$ Minnesota Department of Health (2014).

${ }^{3}$ Toccalino and others (2012).

${ }^{4}$ U.S. Environmental Protection Agency (2013).

established standards, one detected compound, $p$-cresol, was detected at site 452055093105401 (map number 62, fig. 2, table 1), a monitoring well in septic residential land use, at a concentration of $2.9 \mu \mathrm{g} / \mathrm{L}$, as compared with the MDH HRL of $3 \mu \mathrm{g} / \mathrm{L}$. Four of the six most frequently detected compoundsazithromycin, diphenhydramine, tributyl phosphate, and lincomycin - have no health-based water-quality standards or benchmarks.

\section{Environmental Implications}

Samples from bedrock wells, most of which are drinking water wells that are deeper than glacial wells, had a higher percentage of CEC detections than samples from glacial wells. Samples from drinking water wells with detections had three or fewer distinct chemicals detected. One drinking water well completed in a bedrock aquifer had five detections, but 
sulfamethoxazole and carbamazepine were each detected by two analytical methods (table 10 , tables 1-2 through 1-5). The higher DO concentrations and lower specific conductance for the bedrock wells sampled indicate relatively shorter duration flow paths from the land surface to the wells than for glacial wells. Homes that rely on a domestic well as a drinking water source often have a septic system for wastewater disposal (DeSimone and others, 2009; Bremer and Harter, 2012). The frequency of CEC detections in these bedrock drinking water wells is an indicator that these wells are indeed vulnerable to anthropogenic contaminants, potentially from septic system wastewater.

The antibiotic sulfamethoxazole, the most frequently detected CEC, was detected in 11.4 percent of the samples. Most of the detections (11 of 14, or 79 percent) of sulfamethoxazole were in samples from domestic wells or monitoring wells located in areas where septic systems are prevalent. Sulfamethoxazole was detected in 30 percent (8 of 27) of all domestic wells sampled; these wells likely are in proximity to a septic system or leaking sewer lines (Bremer and Harter, 2012). Because of its physical properties, sulfamethoxazole is mobile and not readily degraded in the subsurface environment (National Center for Biotechnology Information, 2013). Although the detections of sulfamethoxazole in samples for this study were several orders of magnitude less than the HBV of $100 \mu \mathrm{g} / \mathrm{L}$ (table 11), the detections nonetheless indicate that this antibiotic is present in domestic wastewater, is mobile in groundwater, and that shallow aquifers in Minnesota are vulnerable to anthropogenic contamination. The antibiotic azithromycin was detected in samples from 5 wells, 3 of which were domestic wells. Like sulfamethoxazole, azithromycin is an antibiotic used by people, and it is expected to be mobile and degrade slowly in the environment (Pfizer, 2012).

Conversely, bisphenol A, the chemical detected second most frequently, was detected primarily in wells in proximity to closed landfills. The only chemical detected at a concentration nearing a health-based water quality standard ( $p$-cresol), was detected at a monitoring well located in septic residential land use. Diphenhydramine, an antihistamine, was detected in samples from 5 wells, 4 of which were monitoring wells not in areas with substantial septic system presence. One of the wells with detectable diphenhydramine was a domestic well completed in a bedrock aquifer.

The greater frequency of detection in wells located in developed land-use settings indicate that domestic, commercial, or industrial wastewater or infiltrating stormwater runoff are likely sources of some of the CECs. Other potential sources of CECs to shallow, vulnerable groundwater include transport and infiltration of CECs present on the land surface from atmospheric deposition, leaking municipal sewer lines, or other unknown sources. The CECs enter wastewater streams from domestic, commercial, industrial, and agricultural sources, and chemicals not removed through a treatment system are discharged to the environment (Ternes and others, 1999).

\section{Summary}

A study of contaminants of emerging concern (CECs) in ambient groundwater in urbanized areas of Minnesota was completed by the U.S. Geological Survey in cooperation with the Minnesota Pollution Control Agency. For this study, water samples were collected from November 2009 through June 2012 from 118 wells located in different land-use settings. The sampled wells primarily were screened in vulnerable sand and gravel aquifers (surficial and buried glacial aquifers) or vulnerable bedrock aquifers such as the Prairie du ChienJordan aquifer. Sampled well depths ranged from 9 to 285 feet below land surface. Water samples were collected by Minnesota Pollution Control Agency staff. The water samples were analyzed for steroidal hormones, human-use pharmaceutical compounds, human- and animal-use antibiotics, and a broad suite of organic compounds associated with wastewater at U.S. Geological Survey laboratories. Reported detections were censored and not counted as detections in the data analyses if the chemical was detected in a laboratory or field blank at a similar concentration.

During this study, 38 out of 127 CECs analyzed were detected among all water samples collected. Three of the detected CECs, however, were analyzed using two different analytical methods (2080 and 1433 or LCAB), so 35 distinct chemicals were detected. The number of detections of CECs in individual water samples ranged from 0 to 10 . The three wells in proximity to landfills had the most CEC detections. One or more CECs were detected in a total of 43 samples ( 35 percent); no CECs were detected in 80 samples.

CECs detected in more than one sample were azithromycin, carbamazepine, diphenhydramine, lincomycin, sulfamethazine, sulfadiazine, and sulfamethoxazole (human and animal-use pharmaceuticals); camphor (flavor, fragrance); 4-cumylphenol and 4-tert-octylphenol (nonionic detergent metabolites); bromacil (herbicide active ingredient); carbazole and metolachlor (pesticide active ingredients); tris(2chloroethyl) phosphate (plasticizer and flame retardant); cotinine (nicotine metabolite); bisphenol A (plastic and resin component); fluoranthene and pyrene (asphalt components, combustion products); 1,4-dichlorobenzene (moth repellant); tributyl phosphate (corrosion inhibitor); and isopropylbenzene (fuel and paint thinner component). The hormone or hormone metabolites cis-androsterone and mestranol were each detected in one sample. Also detected in one sample each were a fecal indicator and a fecal stench component, 3-beta-coprostanol and 3-methyl- $1 H$-indole, respectively. Chemicals detected in one sample and found in products used for ingestion or topical use were acetaminophen, caffeine, $N, N$-Diethyl-meta-toluamide (DEET), hexahydrohexamethylcyclopentabenzopyran (HHCB), and triethyl citrate. The chemicals indole, 5-methyl$1 H$-benzotriazole, $p$-cresol, tetrachloroethene, and triphenyl phosphate, which are components of different types of industrial products, also were each detected in one sample.

The chemical DEET was detected at the highest concentration of any CEC, at 7.9 micrograms per liter. The antibiotic 
sulfamethoxazole was the most frequently detected CEC, detected in a total of 14 of 123 samples (11.4 percent) by one or both analytical methods that include sulfamethoxazole as an analyte. Most (11 of 14, or 79 percent) of the detections of the antibiotic sulfamethoxazole were in samples from domestic wells or monitoring wells located in areas where septic systems or leaking municipal sewer lines are prevalent. Conversely, bisphenol A, the chemical detected second most frequently, and DEET, detected at the highest concentration, were detected primarily in wells in proximity to closed landfills.

Of the 127 chemicals included for analysis in this study, 28 have established enforceable or non-enforceable healthbased water-quality standards or benchmarks. Fourteen of the 35 detected compounds have established health-based waterquality standards, whereas 21 detected compounds have no established standard or benchmark. All detections in this study were less than health-based water-quality standards. Although most detections were well below established standards, one detected compound, $p$-cresol, was detected at a monitoring well located in septic residential land use at a concentration of 2.9 micrograms per liter $(\mu \mathrm{g} / \mathrm{L})$, as compared with the Health Risk Limit of $3 \mu \mathrm{g} / \mathrm{L}$. Four of the six most frequently detected compounds - azithromycin, diphenhydramine, tributyl phosphate, and lincomycin — have no health-based water-quality standards or benchmarks.

Samples from bedrock wells, most of which are drinking water wells that are deeper than glacial wells, had a higher percentage of CEC detections than samples from glacial wells. Samples from all but one drinking water well with detections had only one or two chemicals detected; one drinking water well completed in a bedrock aquifer had detections of five chemicals. The higher dissolved oxygen concentrations and lower specific conductance for the bedrock wells sampled indicate relatively shorter duration flow paths from the land surface to these wells than for glacial wells. Homes that rely on a domestic well as a drinking water source often have a septic system for wastewater disposal. The frequency of CEC detections in these bedrock drinking water wells is an indicator that these wells are indeed vulnerable to anthropogenic contaminants, potentially from septic system wastewater.

The greater frequency of detection in wells located in developed land-use settings indicate that domestic, commercial, or industrial wastewater or infiltrating stormwater runoff are likely sources of some of the CECs. Other potential sources of CECs to shallow, vulnerable groundwater include transport and infiltration of CECs present on the land surface from atmospheric deposition, leaking municipal sewer lines, or other unknown sources. The CECs enter wastewater streams from domestic, commercial, industrial, and agricultural sources, and chemicals not removed through a treatment system are discharged to the environment.

\section{References Cited}

Adolphson, D.G., Ruhl, J.F., and Wolf, R.J., 1981, Designation of principal water-supply aquifers in Minnesota: U.S. Geological Survey Water-Resources Investigations Report 81-51, 19 p. (Also available at http://pubs.usgs.gov/ wri/1981/0051/report.pdf.)

Andrews, W.J., Masoner, J.R., and Cozzarelli, I.M., 2011, Emerging contaminants at a closed and an operating landfill in Oklahoma: Ground Water Monitoring and Remediation, v. 32, no. 1, p. 120-130. (Also available at http://dx.doi. org/10.1111/j.1745-6592.2011.01373.x.)

Barnes, K.K., Christenson, S.C., Kolpin, D.W., Focazio, M.J., Furlong, E.T., Zaugg, S.D., Meyer, M.T., and Barber, L.B., 2004, Pharmaceuticals and other organic waste water contaminants within a leachate plume downgradient of a municipal landfill: Ground Water Monitoring and Remediation, v. 24 , no. 2, p. 110-126. (Also available at $h t t p: / /$ dx.doi.org/10.1111/j.1745-6592.2004.tb00720.x.)

Bremer, J.E., and Harter, T., 2012, Domestic wells have high probability of pumping septic tank leachate: Hydrology and Earth System Sciences, v. 16, no. 8, p. 2453-2467. (Also available at $h t t p: / / d x . d o i . o r g / 10.5194 /$ hess-16-2453-2012.)

Childress, C.J.O., Foreman, W.T., Connor, B.F., and Maloney, T.J., 1999, New reporting procedures based on longterm method detection levels and some considerations for interpretations of water-quality data provided by the U.S. Geological Survey National Water Quality Laboratory: U.S. Geological Survey Open-File Report 99-193, 19 p. (Also available at http://pubs.er.usgs.gov/publication/ofr99193.)

DeSimone, L.A., Hamilton, P.A., and Gilliom, R.J., 2009, Quality of water from domestic wells in principal aquifers of the United States, 1991-2004 - Overview of major findings: U.S. Geological Survey Circular 1332, 48 p. (Also available at http://pubs.usgs.gov/circ/circ1332/.)

Erickson, M.L., 2012, Steroidal hormones and other endocrine active compounds in shallow groundwater in nonagricultural areas of Minnesota-Study design, methods, and data, 2009-10: U.S. Geological Survey Data Series 663, 9 p., last accessed December 26, 2013, at http://pubs.usgs.gov/ $d s / 663 /$.

Falteisek, Jan, 2013, County Atlas - Regional Assessment Program: Minnesota Department of Natural Resources, accessed May 3, 2013, at http://www.dnr.state.mn.us/waters/ groundwater_section/mapping/index.html. 
Foreman, W.T., Gray, J.L., ReVello, R.C., Lindley, C.E., Losche, S.A., and Barber, L.B., 2012, Determination of steroid hormones and related compounds in filtered and unfiltered water by solid-phase extraction, derivatization, and gas chromatography with tandem mass spectrometry: U.S. Geological Survey Techniques and Methods, book 5, chap. B9, 118 p. (Also available at http://pubs.usgs.gov/tm/5b9/.)

Furlong, E.T., Werner, S.L., Anderson, B.D., and Cahill, J.D., 2008, Determination of human-health pharmaceuticals in filtered water by chemically modified styrene-divinylbenzene resin-based solid-phase extraction and high-performance liquid chromatography/mass spectrometry U.S. Geological Survey Techniques and Methods, book 5, chap. B5, 56 p. (Also available at http://pubs.usgs.gov/tm/tm5b5/.)

Halling-Sørenson, B., Nors Nelson, S., Lanzky, P.F., Ingerslev, F., Holten Lutzhøft, H.C., and Jørgenson, S.E., 1998, Occurrence, fate and effects of pharmaceutical substances in the environment-A review: Chemosphere, v. 36, no. 2, p. 357-393. (Also available at $h t t p: / / d x . d o i . o r g / 10.1016 /$ S0045-6535(97)00354-8.)

Homer, C., Dewitz, J., Fry, J., Coan, M., Hossain, N., Larson, C., Herold, N., McKerrow, A., VanDriel, J.N., and Wickham, J., 2007, Completion of the 2001 National Land Cover Database for the Conterminous United States: Photogrammetric Engineering and Remote Sensing, v. 73, no. 4, p. 337-341. (Also available at http://www.asprs.org/a/ publications/pers/2007journal/april/highlight.pdf.)

Kenny, J.F., Barber, N.L., Hutson, S.S., Linsey, K.S., Lovelace, J.K., and Maupin, M.A., 2009, Estimated use of water in the United States in 2005: U.S. Geological Survey Circular 1344, 52 p. (Also available at http://pubs.usgs.gov/ circ/1344/.)

Koterba, M.T., 1998, Ground-water data-collection protocols and procedures for the National Water-Quality Assessment Program-Collection, documentation, and compilation of required site, well, subsurface, and landscape data for wells: U.S. Geological Survey Water-Resources Investigations Report 98-4107, 91 p. (Also available at http://pubs.er.usgs. gov/publication/wri984107.)

Kroening, Sharon, 2012, Endocrine active chemicals and other contaminants of emerging concern in Minnesota's groundwater, 2009-2010: Minnesota Pollution Control Agency, 26 p., accessed December 26, 2013, at http://www.pca. state.mn.us/index.php/water/water-types-and-programs/ groundwater/report-on-chemicals-in-groundwater.html.

Kroening, Sharon, 2013, The condition of Minnesota's groundwater, 2007-2011: Minnesota Pollution Control Agency, 59 p.
Lee, K.E., Barber, L.B., Furlong, E.T., Cahill, J.D., Kolpin, D.W., Meyer, M.T., and Zaugg, S.D., 2004, Presence and distribution of organic wastewater compounds in wastewater, surface, ground, and drinking waters, Minnesota, 2000-02: U.S. Geological Survey Scientific Investigations Report 2004-5138, 47 p. (Also available at $h t t p: / / p u b s . u s g s$. gov/sir/2004/5138/.)

Lee, K.E., Schoenfuss, H.L., Jahns, N.D., Brown, G.K., and Barber, L.B., 2008, Alkylphenols, other endocrine-active chemicals, and fish responses in three streams in Minnesota-Study design and data, February-September 2007: U.S. Geological Survey Data Series 405, 44 p., accessed December 26, 2013, at http://pubs.usgs.gov/ds/405/.

Maloney, T.J., ed., 2005, Quality management system, U.S. Geological Survey National Water Quality Laboratory: U.S. Geological Survey Open-File Report 2005-1263, version 1.3 , chapters and appendixes variously paged.

Meyer, M.T., Lee, E.A., Ferrell, G.M., Bumgarner, J.E., and Varns, Jerry, 2007, Evaluation of offline tandem and online solid-phase extraction with liquid chromatography/electrospray ionization-mass spectrometry for analysis of antibiotics in ambient water and comparison to an independent method: U.S. Geological Survey Scientific Investigations Report 2007-5021, 28 p. (Also available at http://pubs.usgs. gov/sir/2007/5021/.)

Minnesota Department of Health, 2014, Human health-based water guidance table, accessed September 8, 2014, at http:// www.health.state.mn.us/divs/eh/risk/guidance/gw/table. html.

Minnesota Department of Natural Resources, 2014, Groundwater Pollution Sensitivity, accessed May 12, 2014, at http://www.dnr.state.mn.us/waters/groundwater_section/ mapping/sensitivity.html.

Minnesota Pollution Control Agency, 1998, Condition groundwater monitoring: accessed on May 8, 2013, at $h t t p: / / w w w$. pca.state.mn.us/index.php/water/water-types-and-programs/ groundwater/groundwater-monitoring-and-assessment/ condition-groundwater-monitoring.html.

Morey, G.B., 1972, Petrology of Keweenawan sandstones in the subsurface of southeastern Minnesota, in Sims, P.K., and Morey, G.B., eds., Geology of Minnesota-A centennial volume: Minnesota Geological Survey, p. 436-449.

Mossler, J.H., 2008, Paleozoic stratigraphic nomenclature for Minnesota: Minnesota Geological Survey Report of Investigations $65,83 \mathrm{p} ., 1 \mathrm{pl}$.

National Center for Biotechnology Information, 2013, Sulfamethoxazole - compound summary: U.S. National Library of Medicine, accessed on December 12, 2013, at http://pubchem.ncbi.nlm.nih.gov/summary/summary. cgi? cid $=5329 \# x 351$. 
Pfizer, 2012, Azithromycin Material Safety Data Sheet: New York, Accessed on December 12, 2013, at http://www.pfizer. com/files/products/material_safety_data/165.pdf.

Rosenberry, D.O., and LaBaugh, J.W., eds., 2008, Field techniques for estimating water fluxes between surface water and ground water: U.S. Geological Survey Techniques and Methods, book 4, chap. D2. (Also available at $h t t p: / / p u b s$. usgs.gov/tm/04d02/.)

Runkel, A.C., Tipping, R.G., Alexander, E.C., Jr., Green, J.A., Mossler, J.H., and Alexander, S.C., 2003, Hydrogeology of the Paleozoic bedrock in southeastern Minnesota: Minnesota Geological Survey Report of Investigations 61, 105 p., 2 pls.

Sando, S.K., Furlong, E.T., Gray, J.L., and Meyer, M.T., 2006, Occurrence of organic wastewater compounds in drinking water, wastewater effluent, and the Big Sioux River in or near Sioux Falls, South Dakota, 2001-2004: U.S. Geological Survey Scientific Investigations Report 2006-5118, 168 p. (Also available at $h t t p: / / p u b s . u s g s . g o v / s i r / 2006 / 5118 /$.)

State of Minnesota, 2013, 2013 Minnesota statutes, chapter $103 \mathrm{H}$, Groundwater protection: accessed May 15, 2013, at https://www.revisor.mn.gov/statutes/?id $=103 \mathrm{~h}$.

Streets, Summer, Ferrey, Mark, and others, 2008, Endocrine disrupting compounds - A report to the Minnesota Legislature: Minnesota Pollution Control Agency, accessed on December 27, 2013, at http://www.pca.state.mn.us/index. php/view-document.html? gid $=3943$.

Ternes, T.A., Stumpf, M., Mueller, J., Haberer, K., Wilken, R.-D., and Servos, M., 1999, Behavior and occurrence of estrogens in municipal sewage treatment plants-I. Investigations in Germany, Canada, and Brazil: Science of the Total Environment, v. 225, no. 1-2, p. 81-90. (Also available at $h t t p: / / d x . d o i . o r g / 10.1016 / S 0048-9697(98) 00334-9$.

Toccalino, P.L., and Hopple, J.A., 2010, The quality of our Nation's waters - Quality of water from public-supply wells in the United States, 1993-2007-Overview of major findings: U.S. Geological Survey Circular 1346, 58 p. (Also available at $h t t p: / / p u b s . u s g s . g o v /$ circ/1346/.)

Toccalino, P.L., Norman, J.E., Booth, N.L., Thompson, J.L., and Zogorski, J.S., 2012, Health-Based Screening Levels-Benchmarks for evaluating water-quality data: U.S. Geological Survey, National Water-Quality Assessment Program, accessed on May 7, 2013, at http://water.usgs.gov/ nawqa/HBSL/.
Tornes, L.H., Stark, J.R., Hoard, C.J., and Smith, E.A., 2007, Anthropogenic organic compounds in ground water and finished water of community water systems in the Greater Twin Cities metropolitan area, Minnesota and Wisconsin, 2004-05: U.S. Geological Survey Scientific Investigations Report 2007-5273, 42 p. (Also available at http://pubs.usgs. gov/sir/2007/5273/.)

U.S. Environmental Protection Agency, 2013, Drinking water contaminants: accessed on May 7, 2013, at http://waterepa. gov/drink/contaminants/.

U.S. Geological Survey, variously dated, National field manual for the collection of water-quality data: U.S. Geological Survey Techniques of Water-Resources Investigations, book 9, chaps. A1-A9, accessed on December 26, 2013, at http:// pubs.water.usgs.gov/twri9A.

U.S. Geological Survey Office of Water Quality, 2011, Application of the result-level ' $v$ ' value qualifier code and 'E' remark code to selected organic results reported by the National Water Quality Laboratory (NWQL): Office of Water Quality Technical Memorandum 2012.01, accessed December 24, 2013, at http://water.usgs.gov/admin/memo/ QW/qw12.01.pdf.

U.S. Geological Survey, 2013, National Water Information System (NWISWeb): U.S. Geological Survey database, accessed on December 26, 2013, at http://waterdata.usgs. gov/nwis.

Wilde, F.D., Radtke, D.B., Gibs, J., and Iwatsubo, R.T., 2004, Processing of water samples (version 2.2, with updates through 2009): U.S. Geological Survey Techniques of Water-Resources Investigations, book 9, chap. A5, accessed May 7, 2013, at http://pubs.water.usgs.gov/twri9A5/.

Winter, T.C., Harvey, J.W., Franke, O.L., and Alley, W.M., 1998, Ground water and surface water-A single resource: U.S. Geological Survey Circular 1139, 79 p. (Also available at http://pubs.usgs.gov/circ/circ1139/.)

Zaugg, S.D., Smith, S.G., Schroeder, M.P., Barber, L.B., and Burkhardt, M.R., 2006, Methods of analysis by the U.S. Geological Survey National Water Quality LaboratoryDetermination of wastewater compounds by polystyrenedivinylbenzene solid-phase extraction and capillary-column gas chromatography/mass spectrometry: U.S. Geological Survey Water-Resources Investigations Report 20014186, 37 p. (Also available at http://pubs.usgs.gov/wri/ wri014186/.)

Zogorski, J.S., Carter, J.M., Ivahnenko, Tamara, Lapham, W.W., Moran, M.J., Rowe, B.L., Squillace, P.J., and Toccalino, P.L., 2006, The quality of our Nation's watersVolatile organic compounds in the Nation's ground water and drinking-water supply wells: U.S. Geological Survey Circular 1292, 101 p. (Also available at $h t t p: / / p u b s . u s g s$. gov/circ/circ1292/.) 
Appendix 


\section{Appendix 1.}

Appendix tables 1-1 through 1-5 that are presented in this section of the report are provided as separate worksheets in a single Microsoft ${ }^{\circledR}$ Excel spreadsheet available at $h t t p: / / p u b s . u s g s . g o v /$ sir/2014/5096/downloads/appendix_tables.

Table 1-1. Physical properties in unfiltered groundwater, Minnesota, 2009-12.

Table 1-2. Concentrations of chemicals in water samples analyzed at the U.S. Geological Survey National Water Quality Laboratory using laboratory schedule 1433 for analysis of wastewater indicator chemicals, 2009-12.

Table 1-3. Concentrations of chemicals in water samples analyzed at the U.S. Geological Survey National Water Quality Laboratory using laboratory schedule 2080 for analysis of pharmaceutical chemicals, 2009-12.

Table 1-4. Concentrations of chemicals in water samples analyzed at the U.S. Geological Survey National Water Quality Laboratory using laboratory schedule 2434 for analysis of hormones and related chemicals, 2010-12.

Table 1-5. Concentrations of chemicals in water samples analyzed at the U.S. Geological Survey Organic Geochemistry Research Laboratory using laboratory schedule LCAB for analysis of antibiotic and other chemicals, 2009-12. 
Publishing support provided by:

Rolla Publishing Service Center

For more information concerning this publication, contact: Director, USGS Minnesota Water Science Center 2280 Woodale Drive

Mounds View, Minnesota 55112

(763) 783-3100

Or visit the Minnesota Water Science Center Web site at: http://mn.water.usgs.gov/ 

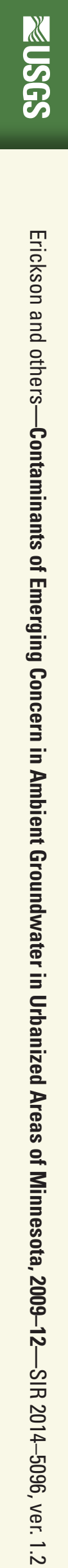